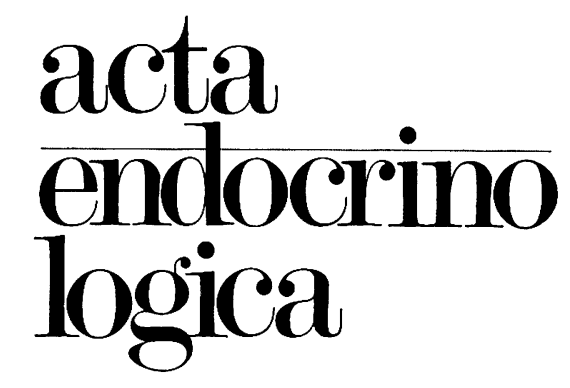

Volume 85

May - August 1977

Copenhagen

\author{
CHIEF EDITOR J. STARUP. DENMARK \\ LOCAL EDITORS T. DECKERT. DENMARK \\ J.-F. DYMLING . SWEDEN \\ B.-A. LAMBERG . FINLAND \\ J. MÜLLER . SWITZERLAND \\ N. NORMAN . NORWAY \\ G. P. van REES . THE NETHERLANDS \\ J. TAMM . FEDERAL REPUBLIC OF GERMANY \\ CONSULTING EDITORS R. BORTH . CANADA \\ C. HAMBURGER . DENMARK
}




\section{HYPOTHALAMUS}

Aro A., Lamberg B.-A. \& Pelkonen R.: Hypothalamic endocrine dysfunction in

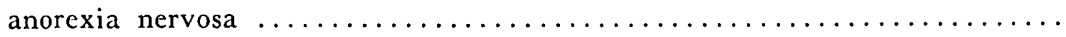

Griffiths E. C., Jeffcoate S. L. \& Holland D. T.: Inactivation of somatostatin by

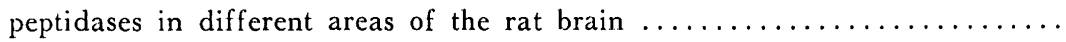

Kalra P. S. \& Kalra S. P.: Temporal changes in the hypothalamic and serum luteinizing hormone-releasing hormone (LH-RH) levels and the circulating ovarian steroids during the rat oestrous cycle $\ldots \ldots \ldots \ldots \ldots \ldots \ldots \ldots \ldots$

Orts R. J., Kocan K. M. \& Johnson R. P.: Antifertility properties of bovine pineal extracts: reduction of ovulation and pre-ovulatory luteinizing hormone

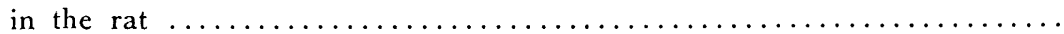

\section{PITUITARY}

Alvarez E. O., Hancke J. L. \& Advis J. P.: Indirect evidences of prolactin involvement in precocious puberty induced by hypothalamic lesions in female rats

Belforte L., Camanni F., Chiodini P. G., Liuzzi A., Massara F., Molinatti G. M., Mïller E. E. \& Silvestrini F.: Long-term treatment with 2-Br- $\alpha$-ergocryptine

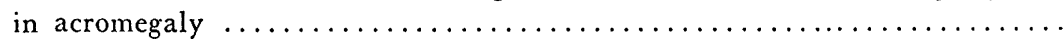

Ching M., Trakulrungsi C., Somana R., Evans A. B. \& Evans E. S.: A re-assessment of the effect of thyrotrophin (TSH) on the tibial plate bioassay for

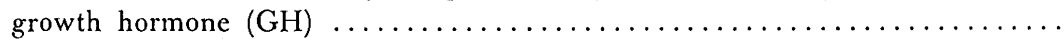

Clemens J. A., Tinsley F. C. \& Fuller R. W.: Evidence for a dopaminergic component in the series of neural events that lead to the pro-oestrous surge of LH

$D^{*}$ Agata R., Andó S., Gulizia S., Condorelli L., Paci C., Scapagnini U. \& Polosa $P$. .: The stimulation of prolactin secretion by sulpiride in "adolescent

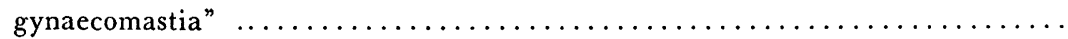

Dickerman Z, Bar-Haim Y., Prager-Lewin R., Kaufman H. \& Laron Z.: Plasma $\mathrm{LH}$ and FSH response to $\mathrm{LRH}$ and plasma testosterone levels in boys with

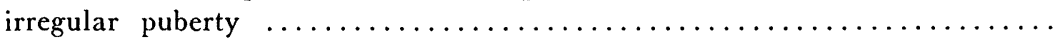

Döhler K.-D., von zur Mühlen A. \& Döhler U.: Pituitary luteinizing hormone $(\mathrm{LH})$, follicle stimulating hormone (FSH) and prolactin from birth to puberty

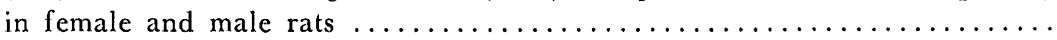

Erhardt F. W \& Scriba P. C.: High molecular thyrotrophin ("big"-TSH) from human pituitaries: preparation and partial characterization $\ldots \ldots \ldots \ldots \ldots$.

Fenske M. \& Wuttke W.: Development of stress-induced pituitary prolactin and

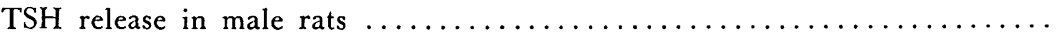

Galton V. A.: Thyroid hormone-binding interactions in cytosol of rat anterior

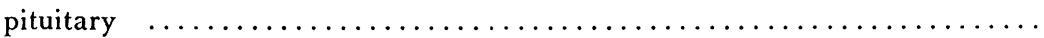

Godden P. M. M., Luck M. R. \& Scanes $C$. G.: The effect of luteinizing hormonereleasing hormone and stercids on the release of $\mathrm{LH}$ and FSH from incubated

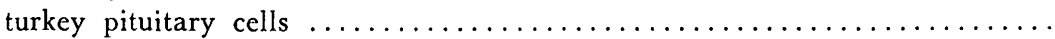

Gray A. B.: Analysis of diameters of human pituitary hormone secretory granules 
Gräf K.-J., Horowski R. \& El Etreby M. F.: Effect of prolactin inhibitory agents on the ectopic anterior pituitary and the mammary gland in rats ...........

ter Haar M. B. \& MacKinnon P. C. B.: Ovarian steroid effects on gonadotrophin output, and on the incorporation of $35 \mathrm{~S}$ from methionine into protein of dis-

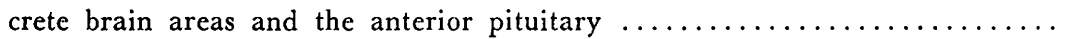

Knight P. J., Hamilton J. M. \& Scanes C. G.: Homologous radioimmunoassay for

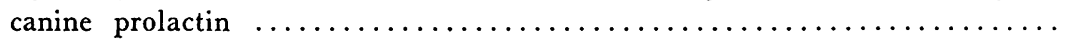

Lindholm J., Dige-Petersen H., Hummer L., Rasmussen P.\& Korsgaard O.: Effect of thyrotrophin releasing hormone (TRH) in patients with pituitary disorders

Neureuther G., Schwandt P. \& Otto J.: Radioimmunoassay for porcine lipotrophic

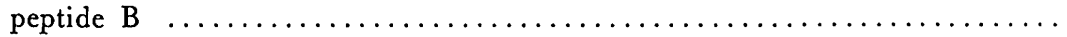

Strauch G., Lego A., Therain F. \& Bricaire H.: Reversible plasma and red blood

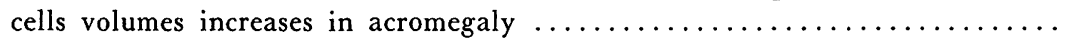

Vadstrup S.: A comparison of the effect of TSH, GH and prolactin on the renal

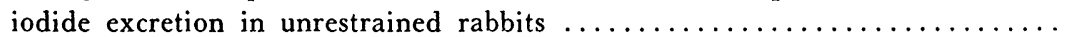

Vilhardt H., Baker R. V. \& Hope D. B.: Subcellular fractionation by centrifugation of homogenates of the neural lobe of the bovine pituitary gland; identification of different pools of hormone in the homogenate and isolation of

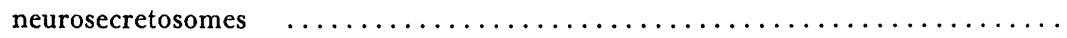

Vogt J. H.: Spontaneous regression of enlargement of the sella turcica and of

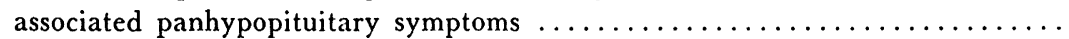

\section{THYROID}

Bastiani P. \& Simon C.: Long-term turnover of thyroid iodine in the rat as studied by the isotopic equilibrium method $\ldots \ldots \ldots \ldots \ldots \ldots \ldots \ldots \ldots \ldots$

Brock Jacobsen B., Petersen B. \& Andersen H.: Changes in serum levels of thyroxine and thyroxine-binding proteins (TBG, TBPA, albumin) induced by

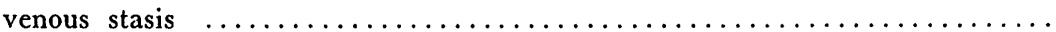

Frey H. M. M. \& Haug E.: Effect of prolonged oral administration of TRH on plasma levels of thyrotrophin and prolactin in normal individuals and in patients with primary hypothyroidism $\ldots \ldots \ldots \ldots \ldots \ldots \ldots \ldots \ldots \ldots \ldots \ldots$

Gluzman B. E., Coleoni A. H., Targounik H. M. \& Niepomniszcze H.: Effects of amiodarone on thyroid iodine metabolism in vitro $\ldots \ldots \ldots \ldots \ldots \ldots \ldots$

Goldman M. \& Bauer S. R.: A comparative study of iodine uptake by thyroid and thymus glands of male and female Sprague-Dawley rats of different ages .... van Hardeveld $C$. \& Kassenaar $A$. A. H.: Influence of experimental hyperthyroidism on skeletal muscle metabolism in the rat $\ldots \ldots \ldots \ldots \ldots \ldots \ldots$

Haug E., Frey H. M. M. \& Sand T.: The thyrotrophin response to thyrotrophin releasing hormone during treatment in patients with Graves' disease ........ Himsworth R. L. \& Kark A. E.: Studies on a case of suppurative thyroiditis ... Kirkegaard C., Faber J., Friis T., Birk Lauridsen U., Rogowski P. \& SiersbakNielsen K.: Intravenous and peroral TRH stimulation in sporadic atoxic goitre Langer P., Kokešová H, Michajlovskij N., Gschwendıová K., Hrčka R. \& Bukovská M.: Rapid disappearance of loading doses of thyroxine from blood and

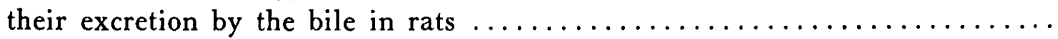

Lemarchand-Béraud T., Holm A.-C. \& Scazziga B. R.: Triiodothyronine and thyroxine nuclear receptors in lymphocytes from normal, hyper- and hypothyroid subjects 
Maier R, Brugger M., Brückner H., Kamber B., Riniker B. \& Rillel W.: Analo-

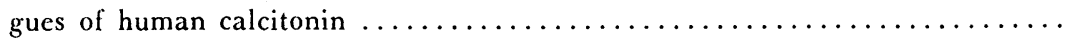

Mosekilde L., Melsen F., Bagger J. P., Myhre-Jensen O. \& Schrvartz Sorensen N.: Bone changes in hyperthyroidism: interrelationships between bone morphometry, thyroid function and calcium-phosphorus metabolism ............

Mulaisho C. \& Utiger R. D.: Serum thyroxine-binding globulin: determination by competitive ligand-binding assay in thyroid disease and pregnancy .........

Nistrup Madsen S.: Thyroid function and plasma cyclic AMP response to intra-

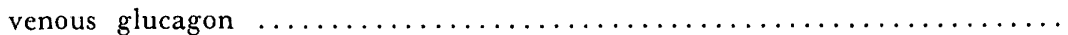

Ochi Y., Yoshimura M., Hachiya T.\& Miyazaki T.: Distribution of LATS activity

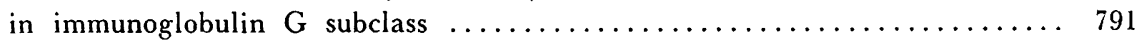

Parker J. L. $W^{\prime}$., Ratcliffe J. G. \& Alexander W. D.: Sporadic non-toxic goitre 497

Platzer S., Fill H., Riccabona G., Glatzl J., Seidl J., Cenderelli G., Migliardi M., Varetto $H$. \& Costa A.: Endemic goitre in Alto Adige (Italy) ............

Triggs S. M. \& Williams E. D.: Experimental carcinogenesis in the rat thyroid

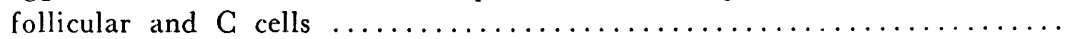

Valenta L. J., Strosberg A. D., Valenta V. \& Jaton J.-C.: Iodopeptides from

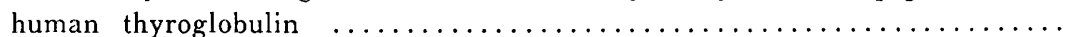

Volpert E. M. \& Prezyna A. P.: Transplantable thyroid tumour in rats: iodoamino acid distribution in successive tumour generations $\ldots \ldots \ldots \ldots \ldots \ldots$

Wall J. R., Gray B. \& Greenwood D. M.: Total and "activated" peripheral blood $\mathrm{T}$ lymphocytes in patients with thyroid disorders $\ldots \ldots \ldots \ldots \ldots \ldots \ldots \ldots$

Westgren U., Ahrén B., Burger A. \& Melander A.: Stimulation of peripheral $\mathrm{T}_{3}$ formation by oral but not by intravenous glucose administration in fasted

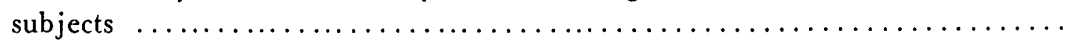

Westgren U., Melander A., Wåhlin E. \& Lindgren J.: Divergent effects of 6propylthiouracil on 3,5,3'-triiodothyronine $\left(\mathrm{T}_{3}\right)$ and $3,3^{\prime}, 5^{\prime}$-triiodothyronine

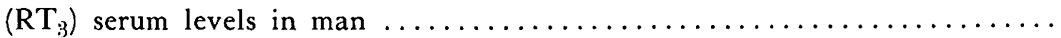

Zaninovich A. A., Boado R., Degrossi O. \& Matty A. J.: In vivo studies on thyroxine and triiodothyronine metabolism in the rat $\ldots \ldots \ldots \ldots \ldots \ldots$

\section{PARATHYROID}

Dietel M., Dorn G., Montz R. \& Allenähr E.: The effect of calcium and dibutyryl-cAMP on the secretion of parathyroid hormone by human parathyroid

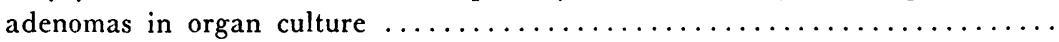

\section{MAMMARY GLANDS}

Peters J. M.: The importance of insulin, cortisol, progesterone and prolactin for the mammotrophic effect of pregnant rat serum

\section{PANCREAS}

Claro A., Grill V., Efendić S. \& Luft R.: Studies on the mechanisms of somato-

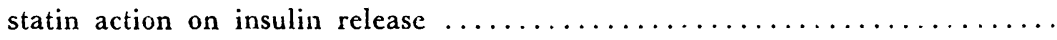

Edén S., Albertsson-Wikland K., Rosberg S. \& Isaksson O.: Effect of insulin and adrenaline on cyclic AMP in the diaphragm of normal and diabetic rats .... 
Efendić S., Lins P. E., Luft R., Sievertsson H. \& Westin-Sjödal G.: Studies on the mechanism of somatostatin action on insulin release ...............

Eigenmann J. E., Becker M., Kammermann B., Leemann W., Heimann R., Zapf J. \& Froesch E. R.: Decrease of non-suppressible insulin-like activity after pan-

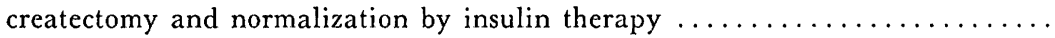

Eigenmann J. E., Francke-Mäder M., Zapf J. \& Froesch E. R.: Non-suppressible insulin-like activity during acute metabolic and endocrine changes in dogs ....

Enk $B .:$ Insulin secretion in insulin-requiring diabetics before and during insulin

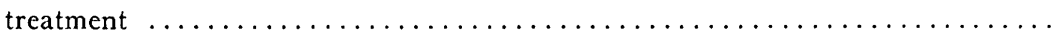

Hanssen K. F. \& Torjesen P. A.: Increased serum prolactin in diabetic ketoacidosis; correlation between serum sodium and serum prolactin concentration

Ludvigsson J. \& Heding L. G.: C-peptide in diabetic children after stimulation with glucagon compared with fasting C-peptide levels in non-diabetic children

Trimble E. R., Buchanan K. D., Hadden D. R. \& Montgomery D. A. D.: Secretin:

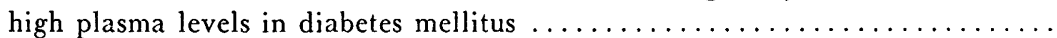

\section{I V E R}

Seilz H. J., Krone W. \& Tarnowski W.: Physiological regulation of rat liver phosphoenolpyruvate carboxykinase (GTP) by insulin. Insignificance of a cyclic

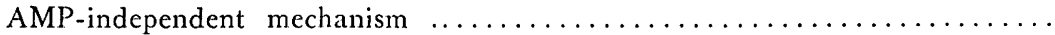

\section{A D RENALS}

Fehér T., Bodrogi L., Fehér K. G., Poleczin E. \& Kölcsey I. S.: Free and solvolysable dehydroepiandrosterone and androsterone in blood of mammals under physiological conditions and following administration of dehydroepiandro-

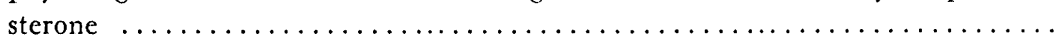

Hilfenhaus M.: Urinary aldosterone excretion rate and plasma aldosterone concentration in the rat: effect of ACTH, DOC, furosemide and of changes in

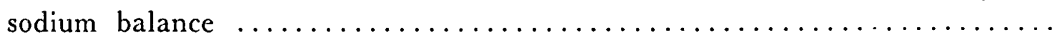

Honn $K V$. \& Chavin $W .:$ In vitro temporal cAMP and cortisol responses to

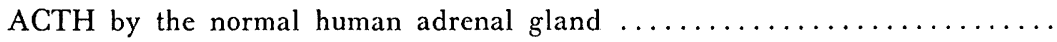

Kolanowski J., Esselinckx W., Nagant de Deuxchaisnes C. \& Crabbé J.: Adrenocortical response upon repeated stimulation with corticotrophin in patients

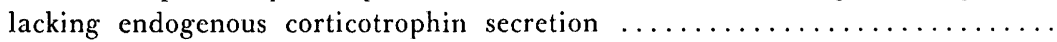

Lombardi G., Oliver C., Lupoli G. \& Minozzi M.: Corticotrophic and melano-

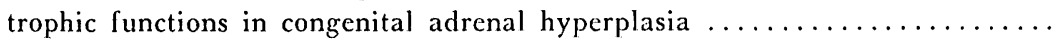

Maschler I., Weidenfeld J., Muller A., Slavin S., Shaeler J., Chorvers I. \& Finkelstein $M .:$ A case of adrenogenital syndrome with aberrant $11 \beta$-hydroxylation

Nussdorfer G. G., Mazzocchi G., Robba C., Belloni A. S. \& Rebuffat P.: Effects of ACTH and dexamethasone on the zona glomerulosa of the rat adrenal cortex: an ultrastructural stereologic study $\ldots \ldots \ldots \ldots \ldots \ldots \ldots \ldots \ldots \ldots$

Schöneshöfer M., L'age M. \& Oelkers W.: Short time kinetics of deoxycorticosterone, deoxycortisol, corticosterone and cortisol during single dose me-

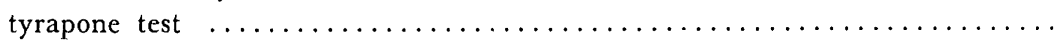

Yamamoto S., Utsu S., Tanioka Y \& Ohsarva N.: Extremely high levels of corticosteroids and low levels of corticosteroid binding macromolecules in plasma

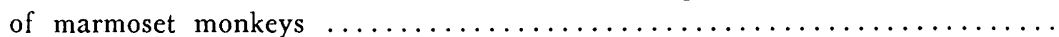


Olgaurd K., Hagen C, Madsen S. \& Hummer L.: Lack of effect of prolactin inhibition by alpha-bromergocriptine (CB 154) on plasma aldosterone in anephric and non-nephrectomized patients on regular haemodialysis $\ldots \ldots \ldots \ldots \ldots$.

\section{OVARIES}

Aono T., Miyzaki M., Miyake A., Kimugusa T., Kurachi K. \& Matsumoto K.: Responses of serum gonadotrophins to LH-releasing hormone and oestrogens

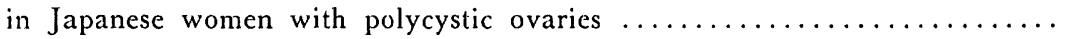

Davy M., Torjesen P. A. \& Aakvaag A.: Demonstration of an FSH receptor in a

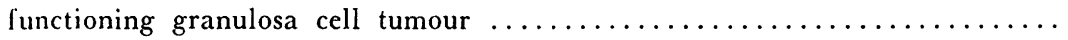

lsaacs A. J. \& Havard C. W. H.: Effect of piperazine oestrone sulphate on serum

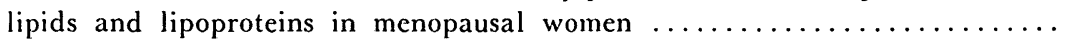

Pillaway D E., Andersen R. N. \& Givens J. R.: Characterization of human ovarian oestradiol-1 $7 \beta$ oxidoreductase activity $\ldots \ldots \ldots \ldots \ldots \ldots \ldots \ldots$

Plas-Roser S., Hassani M. \& Aron C.: The role of follicle-stimulating hormone (FSH) in combination with luteinizing hormone (LH), in oestrogen-induced

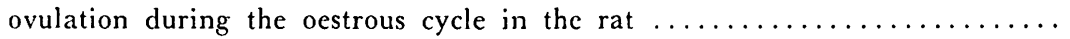

Siebers J. W., Pelers F. \& Engel $W^{\prime}$. . Ovarian HCG-binding capacity during the

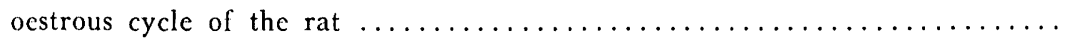

Wagner W. C., Strohbehn R. E. \& Larson P. A.: Effect of local or parenteral application of ACTH or hydrocortisone on bovine corpus luteum function ....

\section{U T ER US}

Asai $M$ : A new assay method for the determination of oestrogen receptors .. Hagenfeldt K., Landgren B.-M., Plantin L.-O. \& Diczfalusy E.: Trace elements in the human endometrium and decidua $\ldots \ldots \ldots \ldots \ldots \ldots \ldots \ldots \ldots \ldots \ldots$

Jelínek J. \& Jelínková $M$. : Rat endometrium enzymes in 4-day oestrous cycle

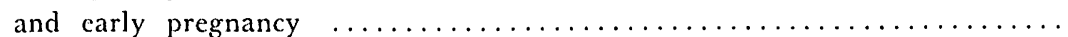

\section{PRE G NANCY}

Jeppsson S., Rannevik G. \& Thorell J. I.: Pituitary gonadotrophin secretion during

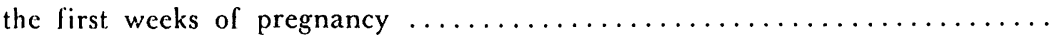

Svan H., Hall K., Ritzén M., Takano K. \& Skollner A.: Somatomedin A and B in serum from neonates, their mothers and cord blood .................

Tozensley J. D. \& Pepe G. J.: Serum dehydroepiandrosterone and dehydroepiandrosterone sulphate in baboon (Papio papio) pregnancy $\ldots \ldots \ldots \ldots \ldots$

\section{TESTES}

Job J.-C., Gendrel D., Safar A., Roger M. \& Chaussain J.-L.: Pituitary LH and FSH and testosterone secretion in infants with undescended testes .......... 


\section{ISCELLANEOUS}

Adamopoulos D., Vlassopoulos C., Seitanides B., Contoyiannis P. \& Vassilopoulos $P .:$ The relationship of sex steroids to uric acid levels in plasma and

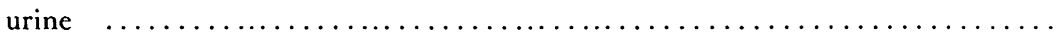

Bartsch W., Horst H.-J., Becker H. \& Nehse G.: Sex hormone binding globulin binding capacity, testosterone, $5 \alpha$-dihydrotestosterone, oestradiol and prolactin in plasma of patients with prostatic carcinoma under various types of hor-

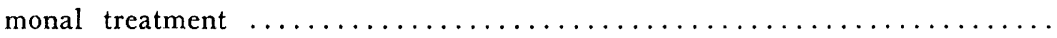

Bolt $H$ M., Bolt M. \& Kappus H.: Interaction of rifampicin treatment with pharmacokinetics and metabolism of ethinyloestradiol in man ...............

Kanke Y., Nishina H., Mori Y. \& Bashey R. I.: Study of the effect of oestradiol on hexosamine-containing substances and a possible receptor in the skin of

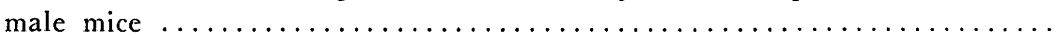

Kley H. K., Bartmann E. \& Krüskemper H. L.: A simple and rapid method to measure non-protein-bound fractions of cortisol, testosterone and oestradiol by equilibrium dialysis: comparison with centrifugal filtration $\ldots \ldots \ldots \ldots \ldots$

Misra D, Gupta D. N. \& Karkun J. N.: Contribution of lactic acid by the ampullary and isthmic parts of rabbit Fallopian tube under altered hormonal con-

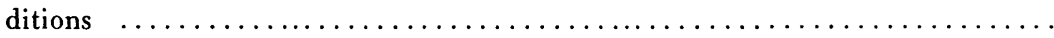

Trygstad $O$. \& Foss 1. : Congenital generalized lipodystrophy and experimental lipoatrophic diabetes in rabbits treated successfully with fenfluramine ...... de Visser $J$ \& van der Vies $J$ : Oestrogenic activity of oestradiol-decanoate after

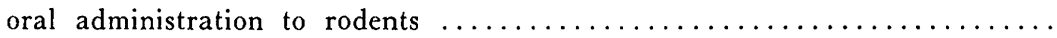

Wahlberg P., Carlsson E. \& Brandt U.: Lack of acute effect of triiodothyronine on noradrenaline responses of isolated sympathectomized cat hearts ........ 
Aakvaag A., 615

Adamopoulos D., 198

Advis J. P., 11

Ahrén B., 526

Albertsson-Wikland K., 806

Alexander W. D., 497

Altenähr E., 541

Alvarez E. O., 11

Andersen H., 39

Andersen R. N., 624

Andó S., 692

Aono T., 840

Aro A., 673

Aron C., 151

Asai M., 855

Bagger J. P., 515

Baker R. V., 300

Bar-Haim Y, 456

Bartmann E., 209

Bartsch W., 650

Bashey R. I., 429

Bastiani P., 357

Bauer S. R., 64

Becker H., 650

Becker M., 818

Belforte L., 235

Belloni A. S., 608

Birk Lauridsen U., 508

Boado R., 351

Bodrogi L., 126

Bolt H. M., 189

Bolt M., 189

Brandt U., 220

Bricaire H., 465

Brock Jacobsen B., 39

Brugger M., 102

Brückner H., 102

Buchanan K. D., 799

Bukovská M., 531

Burger A., 526

Camanni F., 235

Carlsson E., 220
Cenderelli G., 325

Chavin W., 823

Ching M., 25

Chiodini P. G., 235

Chaussain J.-L., 644

Chowers I., 832

Claro A., 379

Clemens J. A., 18

Coleoni A. H., 781

Condorelli L., 692

Contoyiannis P., 198

Costa A., 325

Crabbé J., 595

D'Agata R., 692

Davy M., 615

Degrossi O., 351

Dickerman Z., 456

Diczfalusy E., 406

Dietel M., 541

Dige-Petersen H., 479

Dorn G., 541

Döhler K.-D., 718

Döhler U., 718

Edén S., 806

Edendić S., 379, 818

Eigenmann J. E., 571, 818

El Etreby M. F., 267

Engel W., 850

Enk B., 559

Erhardt F. W., 698

Esselinckx W., 595

Evans A. B., 25

Evans E. S., 25

Faber J., 508

Fehér K. G., 126

Fehér T., 126

Fenske M., 729

Fill H., 325

Finkelstein M., 832

Foss I., 436

Francke-Mäder M., 571 
Frey H. M. M., 335, 744

Friis T., 508

Froesch E. R., 571, 818

Fuller R. W., 18

Galton V. A., 256

Gendrel D., 644

Givens J. R., 624

Glatzl J., 325

Gluzman B. E., 781

Godden P. M. M., 713

Goldman M., 64

Gray A. B., 249

Gray B., 753

Greenwood D. M., 753

Griffiths E. C., 1

Grill V., 379

Gräf K.-J., 267

Gschwendtová K., 531

Gulizia S., 692

Gupta D. N., 665

ter Haar M. B., 279

Hachiya T., 791

Hadden D. R., 799

Hagen C., 587

Hagenfeldt K., 406

Hall K., 636

Hamilton J. M., 736

Hancke J. L., 11

Hanssen K. F., 372

van Hardeveld C., 71

Hassani M., 151

Haug E., 335, 744

Havard C. W. H., 143

Heding L. G., 364

Heimann R., 818

Hilfenhaus M., 134

Himsworth R. L., 55

Holland D. T., 1

Holm A.-C., 44

Honn K. V., 823

Hope D. B., 300

Horowski R., 267

Horst H.-J., 650

Hrčka R., 531

Hummer L., 479, 587

Isaacs A. J., 143

Isaksson O., 806
Jacobsen B. B., 39

Jaton J.-C., 769

Jeffcoate S. L., 1

Jelínek J., 169

Jelínkova M., 169

Jeppsson S., 177

Job J.-C., 644

Johnson R. P., 225

Kalra P. S., 449

Kalra S. P., 449

Kamber B., 102

Kammermann B., $81 \mathrm{~S}$

Kanke Y., 429

Kappus H., 189

Kark A. E., 55

Karkun J. N., 665

Kassenaar A. A. H., 71

Kaufman H., 456

Kinugasa T., 840

Kirkegaard C., 508

Kley H. K., 209

Knight P. J., 736

Kokan K. M., 225

Kokešová H., 531

Kolanowski J., 595

Korsgaard O., 479

Krone W., 389

Krüskemper H. L., 209

Kurachi K., 840

Kölcsey I. S., 126

L'age M., 109

Lamberg B.-A., 673

Landgren B.-M., 406

Langer P., 531

Laron Z., 456

Larson P. A., 158

Lauridsen U. B., 508

Leemann W., 818

Lego A., 465

Lemarchand-Béraud T., 44

Lindgren J., 345

Lindholm J., 479

Lins P. E., 579

Liuzzi A., 235

Lombardi G., 118

Luck M. R., 713

Ludvigsson J., 364

Luft R., 379, 579

Lupoli G., 118 
MacKinnon P. C. B., 279

Madsen S., 587

Madsen S. N., 760

Maier R., 102

Maschler I., 832

Massara F., 235

Matsumoto K., 840

Matty A. J., 351

Mazzocchi G., 608

Melander A., 345, 526

Melsen F., 515

Michajlovskij N., 531

Migliardi M., 325

Minozzi M., 118

Misra D., 665

Miyaka A., 840

Miyazaki M., 840

Miyazaki T., 791

Molinatti G. M., 235

Montgomery D. A. D., 799

Montz R., $54 \mathrm{l}$

Mori Y., 429

Mosckilde L., 515

Mulaisho C., 314

Muller A., 832

von zur Mühlen A., 718

Müller E. E., 235

Myhre-Jensen O., 515

Nagant de Deuxchaisnes C., 595

Nehse G., 650

Ncureuther G., 291

Niepomniszcze H., 781

Nishina H., 429

Nistrup Madsen S., 760

Nussdorfer G. G., 608

Ochi Y., 791

Oelkers W., 109

Ohsawa N., 398

Oliver C., 118

Orts R. J., 225

Otto J., 291

Paci C., 692

Parker J. L. W., 497

Pelkonen R., 673

Pepe G. J., 415

Peters F., 850
Peters J. M., 548

Petersen B., 39

Pittaway D. E., 624

Plantin L.-O., 406

Plas-Roser S., 151

Platzer S., 325

Polosa P., 692

Poteczin E., 126

Prager-Lewin R., 456

Prezyna A. P., 93

Rannevik G., 177

Rasmussen P., 479

Ratcliffe J. G., 497

Rebuffat P., 608

Riccabona G., 325

Riniker B., 102

Rittel W., 102

Ritzén M., 636

Robba C., 608

Roger M., 644

Rogowski P., 508

Rosberg S., 806

Safar A., 644

Sand T., 335

Scanes C. G., 713, 736

Scapagnini U., 692

Scazziga B. R., 44

Schwandt P., 291

Schwartz Sørensen N., 515

Schöneshöfer M., 109

Scriba P. C., 698

Seidl J., 325

Seitanides B., 198

Seitz H. J., 389

Shaefer J., 832

Siebers J. W., 850

Siersbæk-Nielsen K., 508

Sievertsson H., 579

Silvestrini F., 235

Simon C., 357

Skottner A., 636

Slavin S., 832

Somana R., 25

Strauch G., 465

Strohbehn R. E., 158

Strosberg A. D., 769

Svan H., 636

Sørensen N. S., 515 
Takano K., 636

Tanioka Y., 398

Targovnik H. M., 781

Tarnowski W., 389

Therain F., 465

Thorell J. I., 177

Tinsley F. C., 18

Torjesen P. A., 372, 615

Townsley J. D., 415

Trakulrungsi C., 25

Triggs S. M., 84

Trimble E. R., 799

Trygstad O., 436

Utiger R. D., 314

Utsu S., 398

Vadstrup S., 488

Valenta L. J., 769

Valenta V., 769

Varetto H., 325

Vassilopoulos P., 198

van der Vies J., 422

Vilhardt H., 300 de Visser J., 422

Vlassopoulos C., 198

Vogt J. H., 684

Volpert E. M., 93

Wagner W. C., 158

Wahlberg P., 220

Wall J. R., 753

Weidenfeld J., 832

Westin-Sjödal G., 579

Westgren U., 345, 526

Williams E. D., 84

Wuttke W., 729

Wåhlin E., 345

Yamamoto S., 398

Yoshimura M., 791

Zaninovich A. A., 351

Zapf J., 571, 818

Ølgaard K., 587 
ACROMEGALY

effects of thyrotrophin releasing hormone in patients with hypophyseal disorders, 479

long-term treatment with 2-bromo- $\alpha$ ergocryptine, 235

reversible plasma and red blood cells volumes increases, 465

\section{ADAPTATION SYNDROME}

stress-induced release of prolactin and TSH in rats, 729

"ADOLESCENT GYNAECOMASTIA" stimulation of prolactin secretion by sulpiride, 692

\section{ADRENAL CORTEX}

adrenogenital syndrome with aberrant $11 \beta$-hydroxylation, 832

congenital adrenal hyperplasia; corticotrophic and melanotrophic functions, 118

in vitro temporal cyclic AMP and cortisol responses to ACTH by normal human adrenals, 823

pituitary-adrenal function in anorexia nervosa, 673

response to repeated $\mathrm{ACTH}$ stimulation in patients lacking endogenous ACTH secretion, 595

zona glomerulosa; structural changes after long-term administration of ACTH and dexamethasone, 608

\section{ADRENALINE}

effect of insulin and adrenaline on cyclic AMP in diaphragm of normal and diabetic rats, 806

\section{ALBUMIN}

serum levels in man; changes induced by venous stasis, 39

\section{ALDOSTERONE}

excretion rate and plasma concentration in the rat; effects of ACTH, DOC, furosemide and changes in sodium balance, 134

plasma aldosterone in anephric and non-nephrectomized patients on haemodialysis; lack of effect of prolactin inhibition, 587

\section{AMIODARONE}

effect on thyroid iodine metabolism in vilro, 781

\section{AMP}

effect of adrenaline and insulin on cyclic AMP in diaphragm of normal and diabetic rats, 806

effect of dibutyryl-cyclic AMP on secretion of parathyroid hormone by human parathyroid adenomas in organ culture, 541

effect of somatostatin on cyclic AMP levels and phosphodiesterase activity in isolated rat pancreatic islets, 379 in vitro temporal cyclic AMP response to ACTH by normal human adrenals, 823

plasma cyclic AMP response to intravenous glucagon, 760

\section{ANDROGENS}

free and solvolysable DHEA and A in blood of mammals under physiological conditions and following DHEA, 126

serum DHEA and DHEA sulphate in baboon (Papio papio) pregnancy, 415

\section{ANDROSTERONE}

free and solvolysable DHEA and A in blood of mammals under physiological conditions and following DHEA, 126 
ANOREXIA NERVOSA

hypothalamic endocrine dysfunction, 673

\section{ANTIFERTILITY}

reduction of ovulation and preovulatory $\mathrm{LH}$ in the rat by bovine pineal extracts, 225

\section{ANTITHYROID COMPOUNDS}

6-propylthiouracil; divergent effects on $\mathrm{T}_{3}$ and $\mathrm{RT}_{3}$ serum levels in man, 345

\section{BLOOD}

reversible plasma and erythrocyte volumes increases in acromegaly, 465

\section{BONE}

bone changes in hyperthyroidism; interrelationships between bone morphometry, thyroid function and calciumphosphorus metabolism, 515

\section{BRAIN}

incorporation of $35 \mathrm{~S}$ from methionine into protein of discrete brain areas in rats, 279

peptidases in hypothalamus and other areas of the rat brain; inactivation of somatostatin, 1

\section{2-BROMO- $\alpha$-ERGOCRYPTINE}

effects on precocious puberty induced by hypothalamic lesions, 11

effects on the ectopic adenohypophysis and the mammary gland in rats, 267

long-term treatment in acromegaly, 235

prolactin inhibition by 2-bromo- $a$ ergocryptine; lack of effect on plasma aldosterone in anephric and nonnephrectomized patients in haemodialysis, 587

2-BUTYL,3-(4-DIETHYLAMINOETIOXY-3,5-DIIODO, BENZOYL) BENZOFURAN see AMIODARONE

\section{CALCITONIN}

analogues of human calcitonin; influence of basic amino acids on hypocalcaemic activity in the rat, 102

\section{CALCIUM}

calcium-phosphorus metabolism in hyperthyroidism, 515

effect of calcium and dibutyryl-cyclic AMP on secretion of parathyroid hormone by human parathyroid adenomas in organ culture, 541 effect of dietary $\mathrm{Ca}$ on experimental carcinogenesis in the rat thyroid follicles and $\mathrm{C}$ cells, 84

hypocalcaemic activity of human calcitonin analogues, 102

\section{CARCINOGENESIS}

effect of dietary $\mathrm{Ca}$ and radiation on experimental carcinogenesis in the rat thyroid follicles and $\mathrm{C}$ cells, 84

\section{CARTILAGE}

effect of thyrotrophin on the tibial plate bioassay for growth hormone, 2.5

\section{CHORIONIC GONADOTROPHIN} ovarian HCG-binding capacity during the oestrous cycle of the rat, 850 plasma concentration during the first weeks of human pregnancy, 177

\section{CHROMATIN}

a new method for determination of oestrogen receptors, 855

\section{C.OMPETITIVE LIGAND-BINDING ASSAY \\ of serum thyroxine-binding globulin. 314}

\section{CONGENITAL ADRENAL HYPER-}

\section{PLASIA}

corticotrophic and melanotrophic functions, 118

\section{CONGENITAL GENERALIZED \\ LIPODYSTROPHY}

successful treatment with fenfluramine, 436

\section{CONNECTIVE TISSUES}

effect of oestradiol on hexosaminecontaining substances and a possible receptor in the skin of male mice, 429 


\section{CORPUS LUTEUM}

effect of local and parenteral application of ACTH or cortisol on bovine corpus luteum function, 158

\section{CORTICOSTEROIDS}

dexamethasone; effect of long-term administration on structure of rat zona glomerulosa, 608

high levels of corticosteroids and low levels of corticosteroid-binding macromolecule in plasma of marmoset monkeys, 398

long-term corticosteroid therapy; adrenocortical response to ACTH, 595

short-time kinetics of deoxycorticosterone, deoxycortisol, corticosterone and cortisol during single dose metyrapone test, 109

\section{CORTICOSTERONE}

short-time kinetics during single dose metyrapone test, 109

\section{CORTICOTROPHIN}

adrenocortical response to repeated ACTH stimulation in patients lacking endogenous ACTH secretion, 595

corticotrophic function in congenital adrenal hyperplasia, 118

effect of local or parenteral application on bovine corpus luteum function, 158

effect of long-term administration on structure of rat zona glomerulosa, 608

effect on aldosterone excretion rate and plasma aldosterone in the rat, 134

effect on corticosteroids in plasma of marmoset monkeys, 398

in vitro temporal cyclic AMP and cortisol response to ACTH by normal human adrenals, 823

\section{CORTISOL}

assay of non-protein-bound cortisol by equilibrium dialysis, 209 effect of local or parenteral application on bovine corpus luteum function, 158

importance for the mammotrophic effect of pregnant rats' serum, 548

in vitro temporal cortisol response to ACTH by normal human adrenals, 823

short-time kinetics during single dose metyrapone test, 109

\section{CORTISONE}

short-time kinetics during single dose metyrapone test, 109

\section{CRYPTORCHIDISM}

in infants; testosterone secretion and $\mathrm{LH}$ and FSH response to LH-RH, 644

\section{DEHYDROEPIANDROSTERONE}

free and solvolysable DHEA and A in blood of mammals under physiological conditions and following DHEA, 126

serum DHEA and DHEA sulphate in baboon (Papio papio) pregnancy, 415

\section{DEOXYCORTICOSTERONE}

effect on aldosterone excretion rate and plasma aldosterone in the rat, 134

short-time kinetics during single dose metyrapone test, 109

\section{DEOXYCORTISOL}

short-time kinetics during single dose metyrapone test, 109

\section{DEXAMETHASONE}

effect of long-term administration on structure of rat zona glomerulosa, 608

\section{DIABETES MELLITUS}

diabetic ketoacidosis; increased serum prolactin levels; correlation with serum sodium, 372

effect of insulin and adrenaline on cyclic AMP in the diaphragm of diabetic rats, 806 
insulin secretion in insulin-requiring diabetics before and during insulin treatment, 559

C-peptide and total IRI in diabctic children after administration of glucagon; comparison with nondiabetic children, 364

secretion; high levels in diabetes mellitus, 799

\section{DIHYDROPROGESTERONE}

effect on incorporation of $35 \mathrm{~S}$ from methionine into proteins from brain and hypophysis in rats, 279

effect on pro-oestrous $\mathrm{LH}$ surge in rats, 279

\section{$5 a$-DIHYDROTESTOSTERONE}

in plasma of patients with prostatic carcinoma under hormonal treatment, 650

\section{DOPAMINE}

participation in the neural events leading to the pro-oestrous surge of LH, 18

\section{ENDOMETRIUM}

trace elements in the human endometrium, 406

\section{ENZYMES}

characterization of human oestradiol$17 \beta$ oxidoreductase activity, 624

1 i $\beta$-hydroxylation; aberrant activity in a case of adrenogenital syndrome, 832

peptidase in hypothalamus and other areas of the rat brain; inactivation of somatostatin, 1

phosphodiesterase activity in isolated rat pancreatic islets; effect of somatostatin, 379

phosphoenolpyruvate carboxykinase in rat liver; physiological regulation, 389

rat endometrium enzymes in 4-day oestrous cycle and early pregnancy, 169

\section{ERYTHROCYTES}

reversible volume increases in acromegaly, 465

\section{ETHINYLOESTRADIOL}

interaction of rifampicin treatment with pharmacokinetics and metabolism of ethinyloestradiol, 189

\section{EQUILIBRIUM DIALYSIS}

assay of non-protein-bound cortisol, testosterone and oestradiol; comparison with centrifugal filtration, 209

\section{FALLOPIAN TUBE}

of rabbits; contribution of lactic acid under altered hormonal conditions. 665

\section{FASTING}

stimulation of peripheral $T_{3}$ formation by oral but not by iv glucose administration in fasted subjects, $\mathbf{5 2 6}$

\section{FENFLURAMINE}

congenital generalized lipodystrophy and experimental lipoatrophic diabetes in rabbits treated successfully with fenfluramine, 436

\section{FOLLICLE STIMULATING HORMONE}

FSH, LH and prolactin from birth to puberty in rats, 718

FSH receptor in a functioning granulosa cell tumour. 615

release of FSH and LH from incubated turkey pituitary cells, 713

response to LH-RH and oestrogens in Japanese women with polycystic ovaries, 840

response to LH-RH and plasma testosterone levels in boys with irregular puberty, 456

response to LH-RH in infants with undescended testes, 644.

role of FSH in combination with $\mathrm{LH}$ on ocstrogen-induced ovulation in the rat, 151

secretion during the first weeks of human pregnancy, 177

\section{FUROSEMIDE}

effect on aldosterone excretion and plasma aldosterone in the rat, 134 


\section{GERONTOLOGY}

iodine uptake by thyroid and thymus in rats of different ages, 64

\section{GLOBULIN}

distribution of LATS in immunoglobulin G subclass, 791

iodopeptides from human thyroglobulin, 769

sex hormone binding globulin in patients with prostatic carcinoma under hormonal treatment, 650 thyroxine-binding globulin; changes induced by venous stasis, 39

thyroxine-binding globulin; determination by competitive ligand-binding assay in thyroid diseases and in pregnancy, 314

\section{GLUCAGON}

C-peptide and total IRI in diabetic children after administration of glucagon, 364

thyroid function and plasma cyclic AMP response to intravenous glucagon, 760

\section{GLUCOSE}

stimulation of peripheral $T_{3}$ formation by oral but not by iv administration in fasted subjects, 526

\section{GLYCOSAMINOGLYCANS}

in the skin of male rats; effect of oestradiol, 429

\section{GOITRE}

endemic goitre in Alto Adige (Italy), 325

sporadic non-toxic goitre; a long-term follow-up of 36 patients, 497 sporadic non-toxic goitre; intravenous and peroral TRH stimulation, 508

\section{GONADOTROPHINS}

FSH, LH and prolactin from birth to puberty in rats, 718

hypophyseal gonadotrophins; secretion during the first weeks of human pregnancy, 177
LH and FSH response to LH-RH and plasma testosterone levels in boys with irregular puberty, 456

plasma gonadotrophins in a case of functioning granulosa cell tumour, 615

release from incubated turkey pituitary cells, 713

responses to LH-RH and oestrogens in Japanese woman with polycystic ovaries, 840

role of $\mathrm{FSH}$ and $\mathrm{LH}$ in oestrogeninduced ovulation in the rat, 151

\section{GRANULOSA CELL TUMOUR}

demonstration of an FSH receptor, 615 transplantation to nude mice; effects of gonadotrophins, 615

\section{GROWTH HORMONE}

assay; effect of thyrotrophin on the tibial plate bioassay, 25

comparison of the effects of $\mathrm{GH}$, prolactin and TSH on renal iodide excretion in unrestrained rabbits, 488 hypothalamic endocrine dysfunction in anorexia nervosa, 673

lacking effect on NSILA-S in dogs, 571

plasma GH in acromegaly; suppression by 2-bromo-a-ergocryptine, 235

GYNAECOMASTIA

stimulation of prolactin secretion by sulpiride in "adolescent gynaecomastia", 692

\section{HAEMOCONCENTRATION}

effect of venous stasis on serum levels of thyroxine-binding proteins in $\operatorname{man}, 39$

HEXOSAMINE

effect of oestradiol on hexosaminecontaining substances in the skin of male mice, 429

\section{HIRSUTISM}

a case of adrenogenital syndrome with aberrant $11 \beta$-hydroxylation, 832 
HUMAN CHORIONIC GONADO-

TROPHIN see CHORIONIC GONADOTROPHIN

\section{$11 \beta$-HYDROXYLATION}

aberrant activity in a case of adrenogenital syndrome, 832

\section{HYPERTHYROIDISM}

bone changes in hyperthyroidism, 515 experimental hyperthyroidism; effect on rat skeletal muscle metabolism, in particular lipolysis, 71

response of cyclic AMP to intravenous glucagon, 760

$\mathrm{T}_{4}$ and $\mathrm{T}_{3}$ nuclear receptors in lymphocytes from hyperthyroid subjects, 44

$\mathrm{T}_{4}$-binding globulin concentration in serum in hyperthyroidism, 314

\section{HYPOCALCAEMIA}

hypocalcaemic activity of human calcitonin analogues, 102

\section{HYPOPHYSIS (ANTERIOR LOBE)}

cytosol fraction of rat pituitary cells; thyroid hormone-binding interactions, 256

ectopic adenohypophysis; effect of prolactin inhibitors in rats, 267 gonadotrophins; response to LH-RH and plasma testosterone levels in boys with irregular puberty, 456 gonadotrophins; response to LH-RH in infants with undescended testes, 644 gonadotrophins; secretion during the first weeks of human pregnancy, 177 high molecular thyrotrophin from human hypophyses, 698

incorporation of $35 \mathrm{~S}$ from methionine into rat hypophyseal protein; effects of ovarian steroids, 279

lipotrophic peptide $B$; radioimmunoassay, 291

$\mathrm{LH}, \mathrm{FSH}$ and prolactin from birth to puberty in rats, 718

LH pro-oestrous surge; dopaminergic component in the neural events leading to the surge in rats, 18 panhypopituitary symptoms; spontaneous regression of enlargement of the sella turcica, 684 pituitary-adrenal function in anorexia nervosa, 673

prolactin inhibitory agents, 267

prolactin involvement in precocious puberty induced by hypothalamic lesions in female rats, 11

release of $\mathrm{LH}$ and $\mathrm{FSH}$ from incubated turkey pituitary cells, 713

role of FSH and LH in oestrogeninduced ovulation in the rat, 151 sccretory granules in man; analysis of diameters, 249

stress-induced release of prolactin and FSH in rats, 729

\section{HYPOPHYSIS (POSTERIOR LOBE) see NEUROHYPOPHYSIS}

\section{HYPOTHALAMUS}

hypothalamic endocrine dysfunction in anorexia nervosa, 673

hypothalamic lesions inducing precocious puberty in female rats; prolactin involvement, 11

hypothalamic LH-RH; temporal changes during the rat oestrous cycle, 449

peptidases in rat hypothalamus; inactivation of somatostatin, 1

\section{HYPOTHYROIDISM}

effect of prolonged oral administration of TRH on plasma TSH and prolactin in normal subjects and in primary hypothyroidism, 744 response of cyclic AMP to intravenous glucagon, 760

$\mathrm{T}_{4}$ and $\mathrm{T}_{3}$ nuclear receptors in lymphocytes from hypothyroid subjects, 44

$\mathrm{T}_{4}$-binding globulin concentration in serum in hypothyroidism, 314

\section{IMMUNOGLOBULIN}

distribution of LATS activity in immunoglobulin $\mathrm{G}$ subclass, 791

\section{IMMUNOLOGY}

homologous RIA for canine prolactin, 736

RIA for porcine lipotrophic peptide B, 291 


\section{INSULIN}

effect of insulin and adrenaline on cyclic AMP in diaphragm of normal and diabetic rats, 806

importance for the mammotrophic effect of pregnant rats' serum, 548

NSILA-S; decreased activity after pancreatectomy and normalization by insulin therapy, 818

NSILA-S during acute metabolic and endocrine changes in dogs, 571

physiological regulation of rat liver phosphoenolpyruvate caboxykinase by insulin, 389

release; mechanism of action of somatostatin, 379,579

secretion in insulin-requiring diabetics before and during insulin treatment, 5.59

total immunoreactive insulin and Cpeptide in diabetic children after administration of glucagon, 364

\section{IODINE}

iodopeptides from human thyroglobulin, 769

long-term turnover of thyroid iodine as studied by the isotopic equilibrium method, 357

metabolism of thyroid iodine; effect of amiodarone, 781

renal iodide excretion in unrestrained rabbits; comparison of the effects of $\mathrm{GH}$, prolactin and $\mathrm{TSH}, 488$

uptake by thyroid and thymus in rats of different ages, 64

\section{ISOTOPIC EQUILIBRIUM METHOD} studies on long-term turnover of thyroid iodine in the rat, 357

\section{KETOACIDOSIS}

increased serum prolactin in diabetic ketoacidosis; correlation with serum sodium, 372

\section{KIDNEYS}

lack of effect of prolactin inhibition on plasma aldosterone in anephric and non-nephrectomized patients on haemodialysis, 587 renal iodide excretion in unrestrained rabbits; comparison of the effects of $\mathrm{GH}$, prolactin and $\mathrm{TSH}, 488$

\section{LACTATION}

radioimmunoassay of prolactin in lactating dogs, 736

\section{LACTIC ACID}

contribution by the rat Fallopian tube under altered hormonal conditions, 665

\section{LANGERHANS' ISLETS}

effect of somatostatin analogues on arginine-induced release of insulin and glucagon from the perfused rat pancreas, 579

effect of somatostatin on cyclic AMP levels and phosphodiesterase activity in isolated rat pancreatic islets, 379

\section{LATS}

distribution of LATS activity in immunoglobulin G subclass, 791

\section{LERGOTRILE MESYLATE}

effect on the pro-oestrous LH surge in rats, 18

\section{LIPIDS}

effect of piperazine oestrone sulphate on serum lipids in menopausal women, 143

\section{LIPOATROPHIC DIABETES}

in rabbits treated successfully with fenfluramine, 436

\section{LIPOLYSIS}

in rat skeletal muscles; effect of experimental hyperthyroidism, 71 radioimmunoassay for porcine lipotrophic peptide B, 291

\section{LISURIDE HYDROGEN MALEATE} effect on the ectopic adenohypophysis and mammary glands in rats, 267

\section{LIVER}

physiological regulation of rat liver phosphoenolpyruvate carboxykinase, 389 


\section{LUTEINIZING HORMONE}

decreased response to $\mathrm{LH}-\mathrm{RH}$ in infants with undescended testes, 644

LH-RH; temporal changes during the rat oestrous cycle, 449

pro-oestrous LH surge in rats; antifertility properties of bovine pineal extracts, 225

pro-oestrous LH surge in rats; effects of lergotrile mesylate and reserpine, 18

pro-oestrous LH surge in rats; effects of ovarian steroids, 279

release of FSH and $\mathrm{LH}$ from incubated turkey pituitary cells, 713

response to LH-RH and plasma testosterone levels in boys with irregular puberty, 456

response to LH-RH in Japanese women with polycystic ovaries, 840

role of FSH in combination with $\mathrm{LH}$ on oestrogen-induced ovulation in the rat, 151

secretion during the first weeks of human pregnancy, 177

serum levels in rats; effect of lergotrile mesylate and reserpine, 18

\section{LYMPHOCYTES}

$\mathrm{T}_{4}$ and $\mathrm{T}_{3}$ nuclear receptors in lymphocytes from normal, hyper- and hypothyroid subjects, 44

total and "activated" peripheral blood $T$ lymphocytes in thyroid disorders, 753

\section{MAMMARY GLANDS}

effect of prolactin inhibitors in rats, 267

mammotrophic effect of pregnant rats' serum; importance of insulin, cortisol, prolactin and progesterone, 548

\section{$\beta$-MELANOCYTE STIMULATING HORMONE}

function in congenital adrenal hyperplasia, 118

\section{MENOPAUSE}

effect of piperazine oestrone sulphate on serum lipids and lipoproteins, 143
METYRAPONE

short-time kinetics of deoxycorticosterone, deoxycortisol, corticosterone and cortisol during single dose metyrapone test, 109

\section{MUSCLES}

effect of experimental hyperthyroidism on rat skeletal muscle metabolism, in particular lipolysis, $7 \mathrm{I}$

\section{NEUROHYPOPHYSIS}

subcellular fractionation of homogenates of the bovine neurohypophysis; identification of hormones in the homogenate and isolation of neurosecretosomes, 300

\section{NEUROSECRETOSOMES}

isolation from bovine neurohypophysis, 300

\section{NORADRENALINE}

lack of acute effect of $T_{3}$ on noradrenaline response of isolated sympathectomized cat hearts, 220

\section{OESTRADIOL}

assay of non-protein-bound oestradiol by equilibrium dialysis, 209

effect on hexosamine-containing substances and possible receptor in the skin of male mice, 429

effect on incorporation of $35 \mathrm{~S}$ from methionine into proteins of brain and hypophysis of rats, 279

effect on pro-oestrous $\mathrm{LH}$ surge in rats, 279

effect on release of $\mathrm{LH}$ and FSH from incubated turkey pituitary cells, 713

oestradiol-decanoate; oestrogenic activity after oral administration to rodents, 422

oestradiol-17 $\beta$ oxidoreductase activity in human ovaries, 624

plasma concentrations during the first weeks of human pregnancy, 177

plasma concentration in a case of functioning granulosa cell tumour, 615 
plasma concentrations in patients with prostatic carcinoma under hormonal treatment, 650

temporal changes in $\mathrm{LH}-\mathrm{RH}$ and ovarian steroids during the rat oestrous cycle, 449

\section{OESTROGENS}

effects on plasma and urinary uric acid in human subjects, 198

ethinyloestradiol; interaction of rifampicin treatment with pharmacokinetics and metabolism of ethinyloestradiol, 189

oestrogenic activity of oestradioldecanoate after oral administration to rodents, 422

oestrogen receptors; a new assay method for determination, 855

response of gonadotrophins to oestrogens and LH-RH in Japanese women with polycystic ovaries, 840

\section{OESTRONE}

piperazine oestrone sulphate; effect on serum lipids and lipoproteins in menopausal women, 143

\section{OESTROUS CYCLE}

ovarian HCG-binding capacity during the oestrous cycle of the rat, 850 pro-oestrous LH surge in rats; dopaminergic component in neural events leading to the surge, 18 rat endometrium enzymes in 4-day oestrous cycle and early pregnancy, 169

temporal changes in hypothalamic and serum LH-RH and ovarian steroids during the rat oestrous cycle, 449

\section{OVARIES}

bovine corpus luteum function; effect of local or parenteral application of ACTH and cortisol, 158

characterization of human ovarian oestradiol-17 $\beta$ oxidoreductase activity, 624

functioning granulosa cell tumour; demonstration of an FSH receptor, 615 ovarian HCG-binding capacity during the oestrous cycle of the rat, 850 polycystic ovaries in Japanese women; gonadotrophin responses to $\mathrm{LH}-\mathrm{RH}$ and oestrogens, 840

\section{OVIDUCT}

contribution of lactic acid by the rabbit Fallopian tube under altered hormonal conditions, 665

\section{OVULATION}

antifertility properties of bovine pineal extracts; reduction of ovulation in the rat, 225

effects of lergotrile mesylate and reserpine on ovulation in rats, 18

oestrogen-induced ovulation in rats; role of FSH in combination with LH, 151

\section{OXIDOREDUCTASE}

characterization of human ovarian oestradiol $-17 \beta$ oxidoreductase activity, 624

\section{PAEDIATRICS}

"adolescent gynaecomastia", 692 boys with irregular puberty, 456

\section{PANCREAS}

effect of somatostatin analogues on arginine-induced release of insulin and glucagon from the perfused rat pancreas, 579

effect of somatostatin on cyclic AMP levels and phosphodiesterase activity in isolated rat pancreatic islets, 379 pancreatectomy; decrease of NSILA-S activity after the operation and normalization by insulin therapy, 818

\section{PANHYPOPITUITARISM}

spontaneous regression of the symptoms, 684

\section{PARATHYROIDS}

effects of $\mathrm{Ca}$ and dibutyryl-cyclic AMP on secretion of parathyroid hormone by human parathyroid adenomas in organ culture, 541 


\section{PEPTIDASES}

in hypothalamus and other areas of the rat brain; inactivation of somatostatin, 1

\section{PHOSPHODIESTERASE ACTIVITY}

in isolated rat pancreatic islets; effect of somatostatin, 379

\section{PHOSPHOENOLPYRUVATE \\ CARBOXYKINASE}

physiological regulation in rat liver, 389

\section{PHOSPHORUS}

calcium-phosphorus metabolism in hyperthyroidism, 515

\section{PINEAL BODY}

antifertility properties of bovine pineal extracts; reduction of ovulation and pre-ovulatory $\mathrm{LH}$ in the rat, 225

\section{PIPERAZINE OESTRONE SULPHATE}

effect on serum lipids and lipoproteins in menopausal women, 143

\section{POLYCYSTIC OVARIES}

responses of gonadotrophins to LH-RH and oestrogens in Japanese women with the syndrome, 840

\section{PREGNANCY}

antifertility properties of bovine pincal extracts in the rat, 225

hypophyseal gonadotrophins; secretion during the first weeks of human pregnancy, 177

mammotrophic effect of pregnant rats' serum, 548

radioimmunoassay of prolactin in pregnant dogs, 736

rat endometrium enzymes in early pregnancy, 169

serum DHEA and DHEA sulphate during pregnancy in the babonn (Papio papio), 415

serum $\mathrm{T}_{4}$-binding globulin; determination in thyroid diseases and in pregnancy, 314 somatomedin A and B in serum from neonates, their mothers and cord blood, 636

trace elements in the human endometrium and decidua, 406

\section{PREGNANEDIONE}

effect on incorporation of $35 \mathrm{~S}$ from methionine into proteins of brain and hypophysis of rats, 279

effect on pro-oestrous LH surge in rats, 279

\section{PROGESTERONE}

effect on incorporation of $3.5 \mathrm{~S}$ from methionine into proteins of brain and hypophysis of rats, 279

effect on plasma and urinary uric acid in human subjects, 198

effect on pro-oestrous LH surge in rats, 279

effect on release of $\mathrm{LH}$ and $\mathrm{FSH}$ from incubated turkey pituitary cells, 713

importance for the mammotrophic effect of pregnant rats' serum, 548 plasma concentrations during the first weeks of human pregnancy, 177 temporal changes in LH-RH and ovarian steroids during the rat oestrous cycle, 449

\section{PROLACTIN}

comparison of the effects of prolactin. $\mathrm{GH}$ and TSH on renal iodide excretion in unrestrained rabbits, 488 homologous radioimmunoassay for canine prolactin, 736

importance for the mammotrophic ef[ect of pregnant rats' serum, 548 increased serum prolactin in diabetic ketoacidosis; correlation with serum sodium, 372

involvement in precocious puberty induced by hypothalamic lesions in female rats, 11

plasma concentrations during the first weeks of human pregnancy, 177 plasma concentrations following prolonged TRH administration in normal subjects and in hypothyroidism. 744 
plasma concentrations in patients with prostatic carcinoma under hormonal treatment, 650

prolactin inhibition by 2 -bromo- $a$ ergocryptine; lack of effect on plasma aldosterone in anephric and non-nephrectomized patients on haemodialysis, 587

prolactin inhibitors; effects on the ectopic adenohypophysis and on the mammary glands in rats, 267

prolactin in male and female rats from birth to puberty, 718

radioimmunoassay of canine prolactin, 736

stimulation of prolactin secretion by sulpiride in "adolescent gynaecomastia", 692

stress-induced prolactin release in rats, 729

\section{6-PROPYLTHIOURACIL}

divergent effects on $\mathrm{T}_{3}$ and $\mathrm{RT}_{3}$ levels in man, 345

\section{PROSTATE}

carcinoma; sex hormone binding globulin, testosterone, $5 \alpha$-DHT, oestradiol and prolactin in plasma of patients under hormonal treatment, 650

\section{PROTEINS}

distribution of LATS in immunoglobulin G subclass, 791

glycoproteins in the skin of male mice; effect of oestradiol, 429

iodopeptides from human thyroglobulin, 769

lipoproteins in menopausal women; effect of piperazine oestrone sulphate, 143

lipotrophic peptide $B$; radioimmunoassay, 291

C-peptides in diabetic and non-diabetic children, 364

serum thyroxine-binding globulin; determination in thyroid diseases and in pregnancy, 314 thyroxine-binding proteins; changes in serum levels induced by venous stasis, 39

\section{PUBERTY}

"adolescent gynaecomastia", 692

boys with irregular puberty; plasma $\mathrm{LH}$ and FSH response to LH-RH and plasma testosterone levels, 456

C-peptide and total immunoreactive insulin in diabetic and non-diabetic children, 364

precocious puberty induced by hypothalamic lesions in female rats; prolactin involvement, 11 prolactin, $\mathrm{LH}$ and FSH from birth to puberty in rats, 718

\section{RADIOIMMUNOASSAYS}

for canine prolactin, 736

for porcine lipotrophic peptide B, 291

\section{RELEASING HORMONES}

LH-RH; decreased gonadotrophin response in infants with undescended testes, 644

LH-RH; effect during the first weeks of human pregnancy and during the menstrual cycle, 177

LH-RH; effect of LH-RH and steroids on release of $\mathrm{LH}$ and $\mathrm{FSH}$ from incubated turkey pituitary cells, 713

LH-RH; plasma LH and FSH responses in boys with irregular puberty, 456

LH-RH; responses of gonadotrophins to LH-RH in Japanese women with polycystic ovaries, 840

I.H-RH; temporal changes during the rat oestrous cycle, 449

TRH; effect of prolonged administration on plasma TSH and prolactin in normal subjects and in hypothyroidism, 744

TRH; intravenous and peroral TRH stimulation in sporadic atoxic goitre; 508

TRH; prolactin responses in dogs, 736 
TRH; TSH response to TRH during treatment of patients with Graves' disease, 335

TRH; TSH response to TRH in anorexia nervosa, 673

TRH; TSH response to TRH in patients with hypophyseal disorders, 479

\section{RESERPINE}

effect on pro-oestrous LH surge in rats, 18

\section{RIFAMPICIN}

interaction of rifampicin treatment with pharmacokinetics and metabolism of ethinyloestradiol in man, 189

\section{SECRETIN}

high plasma levels in diabetes mellitus, 799

\section{SELLA TURCICA}

spontaneous regression of enlargement of the sella and of associated panhypopituitary symptoms, 684

\section{SKELETON}

bone changes in hyperthyroidism; interrelationships between bone morphometry, thyroid function and calcium-phosphorus metabolism, 515

\section{SKIN}

effect of oestradiol on hexosaminecontaining substances and a possible receptor in the skin of male mice, 429

\section{SODIUM}

changes in sodium balance; effect on aldosterone excretion rate and plasma aldosterone in the rat, 134 correlation between serum sodium and serum prolactin concentration in diabetic ketoacidosis, 372

\section{SOMATOMEDIN}

somatomedin $\mathrm{A}$ and $\mathrm{B}$ in serum from neonates, their mothers and cord blood, 636

\section{SOMATOSTATIN}

effect of somatostatin analogues on arginine-induced release of insulin and glucagon from the perfused rat pancreas, 579

effect on insulin release and cyclic AMP in isolated rat Langerhans' islets, 379

inactivation by peptidases in hypothalamus and other areas of the rat brain, 1 .

\section{SOMATOTROPHIN see GROWTH HORMONE}

\section{STRESS see ADAPTATION SYNDROME}

\section{SULPIRIDE}

stimulation of prolactin secretion by sulpiride in "adolescent gynaecomastia”, 692

\section{TESTES}

cryptorchidism; pituitary $\mathrm{LH}$ and FSH and testosterone secretion, 644

\section{TESTOSTERONE}

assay of non-protein-bound testosterone by equilibrium dialysis, 209

effect on plasma and urinary uric acid in human subjects, 198

effect on release of $\mathrm{LH}$ and $\mathrm{FSH}$ from incubated turkey pituitary cells, 713 plasma concentration in patients with prostatic carcinoma under hormonal treatment, 650

plasma LH and FSH responses to plasma testosterone levels in boys with irregular puberty, 456

secretion in infants with undescended testes, 644

\section{THYMUS}

iodine uptake in rats of different ages, 64

\section{THYROGLOBULIN}

iodopeptides from human thyroglobulin, 769

long-term turnover of thyroid iodine in the rat as studied by the isotopic equilibrium method, 357 


\section{THY'ROID}

carcinogenesis (experimental) in rat thyroid follicular and $\mathrm{C}$ cells, 84

diseases; studies on a case of suppurative thyroiditis, 55

diseases; total and "activated" blood T lymphocytes, 753

effect of amiodarone on thyroid iodine metabolism in vitro, 781

endemic goitre in Alto Adige (Italy), 325

function and plasma cyclic AMP response to intravenous glucagon, 760

function in a case of suppurative thyroiditis, 55

function in anorexia nervosa, 673

Graves' disease; TSH response to TRH during treatment of the patients, 335

hyperthyroidism; bone changes, 515 iodine uptake in rats of different ages, 64

primary hypothyroidism; effect of TRH on plasma TSH and prolactin, 744

serum $\mathrm{T}_{4}$-binding globulin; determination in thyroid disease and pregnancy, 314

sporadic non-toxic goitre; a long-term follow-up of 36 patients, 497

sporadic non-toxic goitre; intravenous and peroral TRH stimulation, 508

thyroid iodine; long-term turnover as studied by the isotopic equilibrium method in the rat, 357

thyroid tumour in rats; iodoamino acid distribution in successive tumour generations, 93

$\mathrm{T}_{4}$ and $\mathrm{T}_{3}$ nuclear receptors in lymphocytes from normal, hyper- and hypothyroid subjects, 44

\section{THYROIDITIS}

thyroid function in a case of suppurative thyroiditis, 55 effect on the tibial plate bioassay for growth hormone, 25

high molecular thyrotrophin ("Big"$\mathrm{TSH}$ ) from human pituitaries; preparation and characterization, 698

lack of acute effects on noradrenaline responses of isolated sympathectomized cat hearts, 220

response to prolonged oral administration of TRH in normal subjects and in hypothyroidism, 744

response to TRH in anorexia nervosa, 673

response to TRH in sporadic atoxic goitre, 508

secretion and biological activity in patients with hypophyseal disorders before and during TRH administration, 479

stress-induced $\mathrm{TSH}$ release in rats, 729

\section{THYROXINE}

effect on skeletal muscle metabolism in the rat, 71

iodoamino acid distribution in successive thyroid tumour generations in rats, 93

metabolism in the rat; in vivo studies, 351

rapid disappearance of loading doses of $\mathrm{T}_{4}$ from blood and their excretion by the bile in rats, 531 serum levels of $\mathrm{T}_{4}$ and $\mathrm{T}_{4}$-binding proteins; changes induced by venous stasis, 39

serum levels of $\mathrm{T}_{4}$-binding globulin; determination by competitive ligandbinding assay, 314

$\mathrm{T}_{4}$ and $\mathrm{T}_{3}$ binding interactions in cytosol fraction of rat pituitary cells, 256

$\mathrm{T}_{4}$ nuclear receptors in lymphocytes from normal, hyper- and hypothyroid subjects, 44

\section{TRACE ELEMENTS}

in human endometrium and decidua, 406 


\section{TRIIODOTHYRONINE}

divergent effects of 6-propylthiouracil on $\mathrm{T}_{3}$ and $\mathrm{RT}_{3}$ serum levels in man, 345

iodoamino acid distribution in successive thyroid tumour generations in rats, 93

metabolism in the rat; in vivo studies, 351

peripheral $T_{3}$ formation by oral but not by iv glucose administration in fasted subjects, 526

$\mathrm{T}_{3}$ nuclear receptors in lymphocytes from normal, hyper- and hypothyroid subjects, 44

\section{TUMOURS}

experimental carcinogenesis in the rat thyroid follicular and $\mathrm{C}$ cells; effects of dietary $\mathrm{Ca}$ and radiation, 84

functioning granulosa cell tumours; demonstration of an FSH receptor, 615

hypophyseal tumours; effects of thyrotrophin releasing hormone, 479 parathyroid tumours; effects of Ca and dibutyryl cyclic AMP on secretion of parathyroid hormone by human parathyroid adenomas in organ culture, 541

prostatic carcinoma; endocrine studies in relation to hormonal therapy, 650 transplantable thyroid tumour in rats; iodoamino acid distribution in successive tumour generations, 93

\section{URIC ACID}

plasma and urine levels in hunıan subjects; relationship to sex steroids, 198

\section{UTERUS}

rat endometrium enzymes in 4-day oestrous cycle and early pregnancy, 169

trace elements in the human endometrium and decidua, 406

\section{VIRILIZATION}

aberrant $11 \beta$-hydroxylation in a case of adrenogenital syndrome, 832 
Laboratories for Clinical Chemistry and Endocrinology,

II. Medical Clinic, University of Munich.

Munich, FRG

\title{
HIGH MOLECULAR THYROTROPHIN ("BIG"-TSH) \\ FROM HUMAN PITUITARIES: PREPARATION AND PARTIAL CHARACTERIZATION
}

By

Friedrich W. Erhardl and Peter C. Scriba

\begin{abstract}
A B S T R A C T
Homogenates of human pituitaries were centrifuged at $30000 \times \mathrm{g}$ and the supernatant chromatographed on Sephadex G-100. Approximately $1 \%$ of the radioimmunologically measured total activity of TSH was eluted in the void volume. Rechromatography of this material on Sephadex G-200 usually showed $\mathrm{TSH}$-activity at $\mathrm{K}_{\mathrm{al}}=0.5$ (regular $\mathrm{TSH}$ ), $\mathrm{K}_{\mathrm{al}}=0$ (void volume-TSH) and at $\mathrm{K}_{\mathrm{al}}=0.3$ ("big"-TSH). "Big"..TSH was extracted from the corresponding fractions by alfinity-chromatography with solid phase anti-TSH. It was eluted with $5 \mathrm{~mol} / \mathrm{l}$ ammonium thiocyanate and further characterized:

1. The molecular weight was approximately 200000 by comparison with bovine catalase on Sephadex G-200.

2. Immunoidentity as compared with standard-TSH (M. R. C. 68/38) was shown by parallel dilution curves in the radioimmunoassay.

3. Concanavalin-A-Sepharose adsorbed "big"-TSH, which could be eluted with $a$-methyl-D-mannoside, indicating the glycoprotein nature of "big"-TSH.

4. On polyacrylamide-gel-electrophoresis $\mathrm{pH} 7.5$, "big"-TSH migrated faster $\left(R_{F}=0.32\right)$ than regular TSH $\left(R_{F}=0.1\right)$, indicating a more negatively charged molecule.

5. "Big"-TSH, in contrast to regular $\mathrm{TSH}$, was remarkably stable against $6 \mathrm{~mol} / \mathrm{l}$ guanidine hydrochloride, suggesting a covalently linked (aggregate) structure.
\end{abstract}


6. 1\% mercaptoethanol destroyed the immunological activity of both regular and "big"-TSH.

7. "Big"-TSH was digested by trypsin, under mild conditions, to radioimmunologically active products with molecular weights between "big"and regular TSH, but practically no regular TSH was formed.

8. "Big"-TSH and guanidine-treated "big"-TSH, as well as regular TSH and TSH from the void volume of Scphadex G-200 columns, exhibited biological activity in a cytochemical bioassay in good agreement with the respective immunological activities.

High molecular forms of proteohormones known as "big"-hormones have been described for several years as reviewed by Yalow (1974). Recently, "big"hormones were also observed in the field of pituitary glycoprotein hormones: "big"-LH (Prentice \& Ryan 1975; Graesslin et al. 1976) "big"-TSH (Erhardt 1975; Erhardt \& Scriba 1976) and "big"- $\beta$-TSH (Golstein-Golaire \& Vanhaelst 1975; Kourides et al. 1976). There is still little known about the chemical structure and biological significance of the high molecular species of glycoprotein hormones.

\section{MATERIALS AND METHODS}

\section{Reagents}

Rabbit IgG for coprecipitation in the radioimmunoassays; bovine catalase, equine ferritin for the calibration of Sephadex columns; materials for polyacrylamide-gelelectrophoresis (PAGE): Acrylamide, tetramethylethylenediamine, N,N-methylenebisacrylamide and ammonium persulphate; Triton X 100; $\alpha$-methyl-D-mannoside; trypsin (less than $0.24 \%$ chymotrypsin) and trypsin inhibitor from lima bean were obtained from Serva GmbH (Heidelberg, Germany).

All Sephadex gels (G-75; G-100: G-200; QAE-A-50; Cl-Sepharose 2 B; Con ASepharose) were obtained from Pharmacia Fine Chemicals (Uppsala, Sweden), and sodium phosphate, sodium chloride, sodium EDTA, sodium aride, ammonium thiocyanate, and guanidinc (mostly analytical grade), from Merck AG (Darmstadt, Germany). Bovine albumin (Pentex $\Theta$ ) was purchased from Roth (Munich, Germany). TSH for labelling and anti-TSH for radioimmunoassay were kindly donated by the NIAMDD (Bethesda, Maryland). Anti-TSH for affinity-chromatography was donated by Farbwerke Hoechst AG (Frankfurt, Germany). Sodium 12.5iodide for labelling was also obtained from Hoechst AG. Anti-TSH-serum for affinity chromatography was also produced in our laboratories by immunization of two rabbits with TSH (4 U/mg) purchased from Deutsche Kabi GmbH (Munich, Germany). ICG, Primogonyl® for absorption in the radioimmunoassay of TSH and for immunization of rabbits, was obtained from Schering AG (W-Berlin, Germany). Anti-rabbit prccipitating scrum (donkey) was obtained from Wellcome Itd. (England). "Eppendor" plastic tubes (vol. $1.5 \mathrm{ml}$ ) for all radioimmunoassays were purchased from Netheler \& Hinz (Hamburg, Germany). Human pituitaries obtained at autopsy, usually performed 24-36 h after exitus, were kept frozen at $-29^{\circ} \mathrm{C}$. Pituitaries kept in acetone were also used. 
A: $0.015 \mathrm{~mol} / \mathrm{l}$ sodium phosphate; $0.15 \mathrm{~mol} / 1$ sodium chloride; $0.2 \%$ bovine-albumin; $0.002 \%$ sodium azide; $0.02 \mathrm{~mol} / \mathrm{l}$ EDTA, $\mathrm{pH} 7.4$.

B: As buffer A, with $4.2 \%$ bovine albumin and no EDTA.

C: As buffer A, but without albumin and EDTA.

D: $0.1 \mathrm{~mol} / \mathrm{l}$ sodium phosphate, $\mathrm{pH} 6.5$.

$\mathrm{E}: 0.5 \mathrm{ml} / \mathrm{l}$ sodium carbonate, $\mathrm{pH} 8.6$.

F: As buffer E, but with 2 mol/l sodium chloride, $\mathrm{pH} 8.6$.

$\mathrm{G}$ : $0.1 \mathrm{~mol} / \mathrm{l}$ sodium carbonate; $2 \mathrm{~mol} / \mathrm{l}$ sodium chloride, $\mathrm{pH}$ 8.6.

$\mathrm{H}: 0.1 \mathrm{~mol} / \mathrm{l}$ sodium acetate; $2 \mathrm{~mol} / \mathrm{l}$ sodium chloride, $\mathrm{pH} 4.5$.

I: $0.01 \mathrm{~mol} / 1$ Tris, $\mathrm{pH} 7.5$.

\section{Radioimmunoassays of hTSH, $h L H$ and $h G H$}

Radioimmunoassays were carried out using the double antibody technique and a modular analyzer system (Marschner et al. 1975), RIA-E-6000 laboratorium Prof. Berthold (Karlsruhe, Germany) and Ismatec (Zürich, Switzerland). All hormones were labelled with ${ }^{125}$ I by slight modification of the chloramine-T-method (Greentoood et al. 1963). HTSH was measured with minor modifications as described previously (Erhardt et al. 1973) using the international standard M. R. C. 68/38 (NIMR, Mill Hill, London). HLH was measured using anti-HCG from rabbits from our laboratory, LH for labelling was purchased from Calbiochem (California, USA), and standard L. E. R. 907 obtained from NIAMDD. HGH was measured using rabbit anti-HGH from our laboratory, HGH "reinst" for labelling and "creschormone" for standards from Dcutsche Kabi GmbH (Munich, Germany).

\section{Preparation of "big"-TSH}

4-50 pituitaries were thawed at $4{ }^{\circ} \mathrm{C}$ and homogenized in $5-30 \mathrm{ml}$ cold buffer $\mathrm{C}$ for $1 \mathrm{~min}$ in a Vortex homogenizer at low specd and for $1 \mathrm{~min}$ at high spced. The temperature was allowed to rise to $27^{\circ} \mathrm{C}$. The homogenate was centrifuged for $30 \mathrm{~min}$ at $30000 \times \mathrm{g}$ at $4^{\circ} \mathrm{C}$ in a Beckmann ultracentrifuge type L-40. The red-brown and still turbid supernatant was chromatographed on a Sephex G-100 glass column $(3 \times 130 \mathrm{~cm})$ with buffer $\mathrm{C}$ under hydrostatic pressure (flow rate $10-15 \mathrm{ml} / \mathrm{h}$ ). Fractions from 3-6 ml were collected in glass tubes using fraction collector Linear II, Serva GmbH (Heidelberg, Germany). The hormone activities, TSH, LH and HGH were measured in each fraction in adequate dilutions $\left(10^{0}-10^{5}\right)$ in buffer B. Crude "big"-TSH was eluted constantly in the turbid fractions of the void volume $\left(\mathrm{K}_{\mathrm{iI}}=0\right)$ and was usually measured in 1 to 100 , 1 of the eluates (Fig. 1).

For further purification the "big"-TSH containing fractions were concentrated to a volume of $2-5 \mathrm{ml}$ by ultrafiltration at $4^{\circ} \mathrm{C}$, using collodion bags, obtained by Sartorius AG (Göttingen, Germany).

After centrifugation at $30000 \times \mathrm{g}$ for $30 \mathrm{~min}$, the turbid concentrate was re-chromatographed on Sephadex G-200 under hydrostatic pressure. The columns were previously coated with $20 \mathrm{ml}$ buffer $\mathrm{B}$ and were equilibrated over-night at $4^{\circ} \mathrm{C}$ with elution buffer C; 3-6 $\mathrm{ml}$ fractions were collested (Fig. 2).

\section{Immunization of rabbits}

TSH-antiserum was raised in 2 rabbits, which were each immunized by 4 injections, beginning with $100 \mu \mathrm{g}$ subcutaneously followed by 3 injections of $50 \mu \mathrm{g} \mathrm{TSH}$, all in incomplete Freund's adjuvant. After eight weeks one rabbit showed $50 \%$ binding of [125I]TSH in a final dilution of $1: 100000$. 


\section{Preparation of the anti-TSH-affinity gel}

Activation of $\mathrm{Cl}-$ Scpharose-2 $\mathrm{B}$ by cyanogen bromide purchased from Merck AG (Darmstadt, Germany) was performed according to the instructions of Pharmacia Fine Chemicals. Ten $\mathrm{g}$ of the wet gel cake was suspended in $30 \mathrm{ml}$ buffer $\mathbf{E}$ and reacted with $4 \mathrm{~g}$ cyanogen bromide, dissolved in $20 \mathrm{ml}$ of distilled water. Under continuous control by a glass-electrode and under magnetic stirring, the $\mathrm{pH}$ of the mixture was kept between $\mathrm{pH} 10$ and 11 by dropwise addition of $20 \%$ sodium hydroxide. The temperature was kept below $30^{\circ} \mathrm{C}$ by addition of ice. After 20 min the reaction mixture was filtered through a sintered glass funnel and washed with $500 \mathrm{ml}$ of $0.1 \mathrm{~mol} / \mathrm{l}$ sodium carbonate, $\mathrm{pH} 8.6$.

\section{Binding of anti-TSH-IgG}

The preparation of $\mathrm{IgG}$ was performed using the ion exchange gel QAE-A-50Sepharose according to the instructions of Pharmacia Fine Chemicals, elution was with buffer D, and concentration by ultrafiltration. Five $\mathrm{mg}$ of the $\mathrm{IgG}$ dissolved in $10 \mathrm{ml}$ buffer F was added to $1 \mathrm{~g}$ of the wet, freshly prepared activated Cl-Sepharose-2 B-cake in a polystyrene-beaker and slowly rotated at room temperature for $3 \mathrm{~h}$ continued over-night at $4{ }^{\circ} \mathrm{C}$. The mixture was again filtered over a sintered glass funnel. The optical density of the filtrate at $280 \mathrm{~nm}$ was measured and compared with the light absorption before extraction with the activated gel to calculate roughly the proportion of protein linked to the gel. This varied between $40-90 \%(2-4.5 \mathrm{mg}$ protein $/ \mathrm{g}$ wet Sepharose).

To inactivate the anti-TSH gel it was suspended in $20 \mathrm{ml} \mathrm{of} 1 \mathrm{~mol} / \mathrm{l}$ glycine and rotated for $3 \mathrm{~h}$ at room temperature. After filtration, the affinity gel was repeatedly and alternately washed 10 times with buffer $\mathrm{G}$ and buffer $\mathrm{H}(50 \mathrm{ml}$ each).

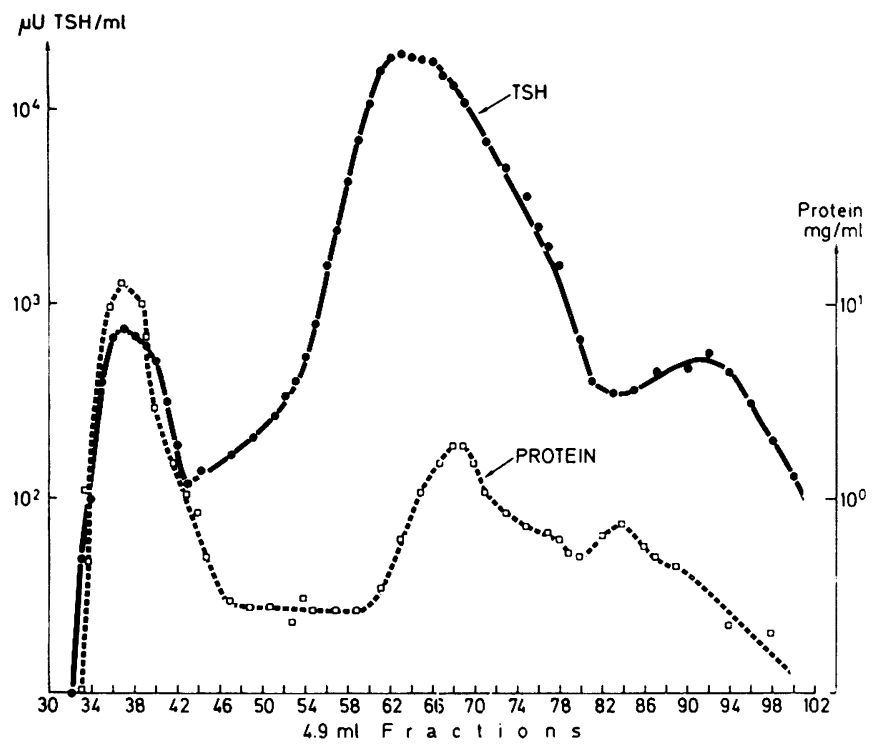

Fig. 1 .

Chromatogram of the $30000 \mathrm{~g}$ supernatant of 4 human pituitaries on Sephadex G-100 $\left(134 \times 3 \mathrm{~cm}\right.$; buffer $\left.\mathrm{C} ; 4^{\circ} \mathrm{C}\right)$. 


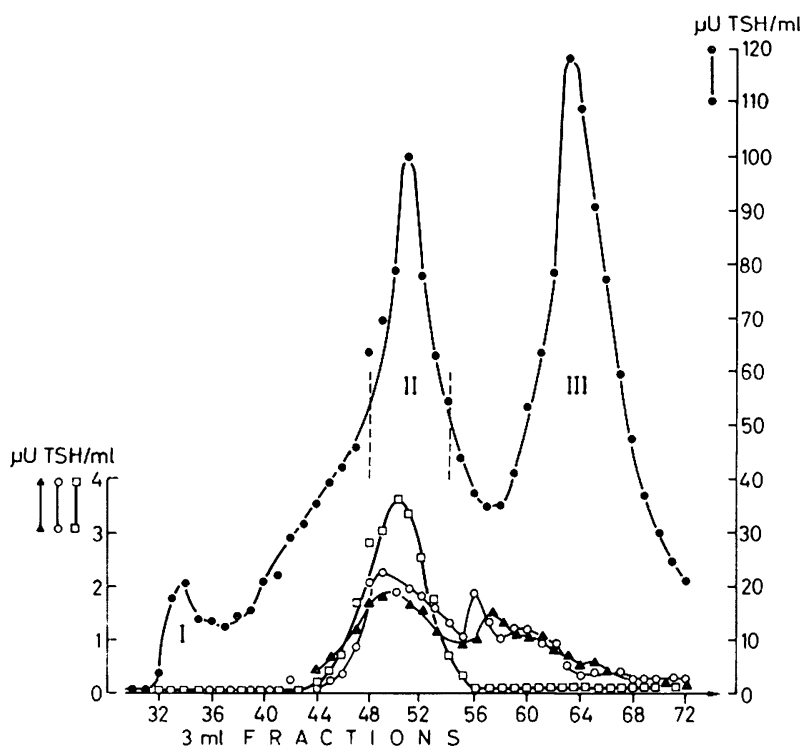

Fig. 2.

Chromatograms of "big"-TSH on Sephadex G-200 before and after mild tryptic digestion. (1.30 $\times 1.7 \mathrm{~cm}$; buffer $\left.\mathrm{C} ; 4^{\circ} \mathrm{C}\right)$.

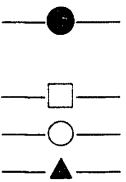

Crude product from Sephadex G-100, showing void volume TSH (I); "big"-TSH (II) and regular TSH (III).

Untreated "big"-TSH, re-chromatographed.

5 min treated with trypsin.

10 min treated with trypsin.

\section{Specific exlraction of "big"-TSH from Sephadex eluates}

One $g$ of wet, freshly prepared affinity-gel was added to the pooled "big"-TSH fractions from the Sephadex chromatography $(20-80 \mathrm{ml})$. After slow rotation at room temperature for $2 \mathrm{~h}$ the gel was filtered (Schott AG, Fritte $1 \mathrm{G} \mathrm{2}$ ) and again repeatedly washed (at least 4 times), alternating between buffer $G$ and bulfer $H$ in order to remove physically adsorbed proteins.

\section{Elution of "big"-TSH from the affinity-gel}

The wet affinity-gel cake loaded with "big"-TSH was suspended in buffer C and poured into a small column (10 ml plastic syringe with filter). "Big"-TSH was eluted with $20 \mathrm{ml}$ of freshly prepared $5 \mathrm{~mol} / \mathrm{l}$ ammonium thiocyanate in distilled water, $\mathrm{pH} 7$, within 10-20 $\mathrm{min}$ and collected in dialysis tubing. Dialysis against 61 distilled water was carried out over $24 \mathrm{~h}$ at $4^{\circ} \mathrm{C}$ with a single change of the outer fluid. The dialyzed "big"-TSH was subsequently concentrated by ultrafiltration through collodion bags to give a final volume of $0.5-1 \mathrm{ml}$. HTSH, HGH and $\mathrm{HLH}$ activity were determined by radioimmunoassay and the protein concentration by lightabsorption at $280 \mathrm{~nm}$ $(0.7$ O. D..290 $\cong 1 \mathrm{mg}$ protein $/ \mathrm{ml})$ to monitor the purification. The product was re-chromatographed on Sephadex G-200 and the fractions collected either in siliconized glass 
tubes, or with $0.2 \mathrm{ml}$ of buffer $\mathrm{B}$ in the bottom of the tubes, in order to reduce adsorption onto the glass. Concentration was again performed by ultrafiltration in collodion bags.

\section{Polyacrylamide-gel-electrophoresis (PAGE)}

PAGE was performed in $0.5 \mathrm{~mol} / \mathrm{l}$ Tris- $\mathrm{HCl}$ at $\mathrm{p} \mathrm{H} 7.5$ (Smith 1968). Bromphenolblue was used as a marker. Two hundred $\mu \mathrm{U}$ of "big"-TSH or TSH, respectively, was applied to the columns (separation gel: $7 \times 0.5 \mathrm{~cm}$, concentration gel $2 \times 0.5 \mathrm{~cm}$ ). At the end of the electrophoresis, the gels were frozen at $-80^{\circ} \mathrm{C}$ for $30 \mathrm{~min}$ and subsequently cut into 45 slices of $1.5 \mathrm{~mm}$ using razor-blades. The slices were each placed in $0.6 \mathrm{ml}$ of buffer B and allowed to elute (for $20 \mathrm{~h}$ ) at room temperature. The TSH-activity in the eluate from each slice was measured by radioimmunoassay (Fig. 5).

\section{Treatment of "big"-TSH and regular TSH with guanidine and Triton $X 100$}

Triton X $100(0.25 \%)$ and guanidine- $\mathrm{HCl}(6 \mathrm{~mol} / \mathrm{l}$ final concentration) were dissolved in $2 \mathrm{ml}$ of "big"-TSH-solution in buffer A ( $\mathrm{pH} \mathrm{5.1),} \mathrm{and} \mathrm{the} \mathrm{mixture} \mathrm{incubated}$ for $1 \mathrm{~h}$ at $37^{\circ} \mathrm{C}$. For comparison, incubations were also performed without guanidine, but with Triton $\mathrm{X} 100$, and without both. The reaction mixtures were chromatographed on Sephadex G-100 or G-200, respectively (Fig. 6).

\section{Mild tryptic digestion of "big"-TSH}

Twenty $\mu \mathrm{g}$ of trypsin in $20 \mu \mathrm{l}$ buffer $\mathrm{C}$ was added to $160 \mu \mathrm{U}$ of "big"-TSH from Sephadex G-200 in $200 \mu l$ of buffer $\mathrm{C}$ in a small siliconized glass tube. No calcium was added. The solution was incubated at $37^{\circ} \mathrm{C}$ for 5 or $10 \mathrm{~min}$, respectively, after which $10 \mu \mathrm{g}$ of lima bean inhibitor in $20 \mu \mathrm{l}$ buffer $\mathrm{C}$ was added in order to stop the reaction. Re-chromatography was performed on $130 \times 1.7 \mathrm{~cm}$ Sephadex G-200, as for the undigested "big"-TSH (Fig. 2).

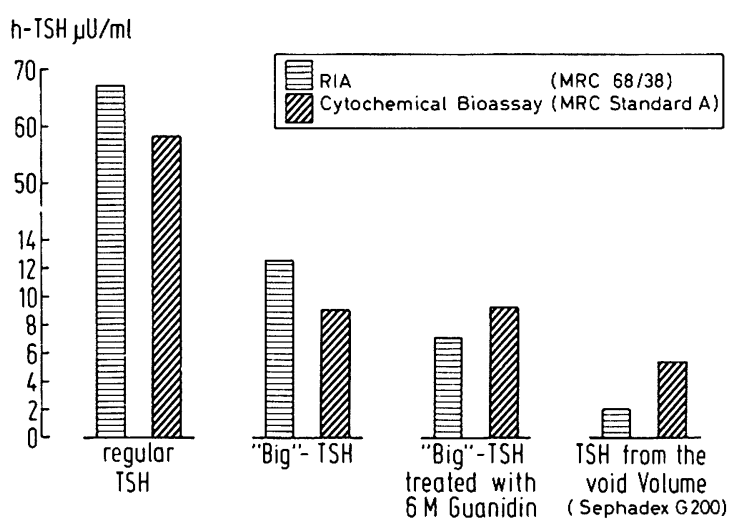

Fig. 3.

Comparison of the radioimmunologically and cytochemically measured TSH-activity of human pituitary TSH-fractions from Sephadex G-200 and of "big"-TSH after treatment with $6 \mathrm{~mol} / \mathrm{l}$ guanidine- $\mathrm{HCl}$ and desalting by re-chromatography. 


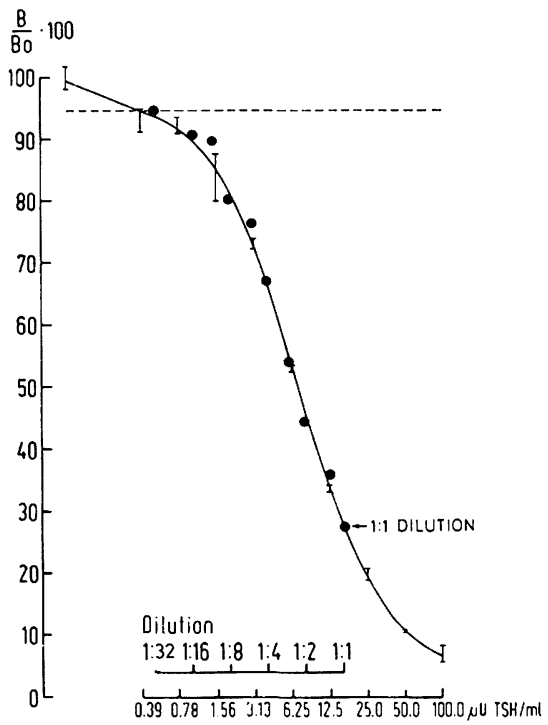

Fig. 4.

Dilution curve of "big"-TSH from affinity chromatography after re-chromatography on Sephadex G-200, compared with TSH-standard M. R. C. 68/38.

- Dilutions of "big"-TSH.

Standard curve.

\section{Mercaploethanol treatment of "big"-TSH}

Ten $\mu l$ mercaptoethanol was added to $160, " \mathrm{U}$ "big"-TSH in $1 \mathrm{ml}$ buffer B. For comparison, M. R. C. 68/38-TSH was treated identically. After $50 \mathrm{~h}$ at $4^{\circ} \mathrm{C}$ and alter $1 \mathrm{~h}$ at $37^{\circ} \mathrm{C}$, aliquots of the reaction mixtures were diluted $1: 10$ with buffer $\mathrm{B}$ to eliminate unspecific effects of mercaptoethanol. TSH-activity was then measured by radioimmunoassay and compared with the activity before treatment. The "big"-TSH was rechromatographed on $1.1 \times 70 \mathrm{~cm}$ Sephadex G-100 (Fig. 7).

\section{Adsorption of "big"-TSH to Con A-Sepharose}

Two $\mathrm{ml}$ of Con A-Sepharose was applied to a $5 \mathrm{ml}$ plastic syringe fitted with a glassfilter, and 80 " UU of "big"-TSH was added in $0.1 \mathrm{ml}$ of buffer C. The column was washed with $8 \mathrm{ml}$ buffer $\mathrm{C}$ and the elution subsequently performed with $10 \mathrm{ml} 0.05$ $\mathrm{mol} / \mathrm{l} \alpha$-methyl-D-mannoside in buffer $\mathrm{C}$. One $\mathrm{ml}$ fractions were collected into Eppendorf vials containing $50 \mu \mathrm{l}$ of buffer B.

\section{Determination of the DNA-content of "big"-TSH}

Ten $\mathrm{mU}$ of "big"-TSH (enriched by affinity chromatography and equivalent to approximately $3 \mu \mathrm{g}$ of regular TSH), dissolved in $0.1 \mathrm{ml}$ of bufier A was treated with $10 \mu \mathrm{l}(1 \mathrm{mg} / \mathrm{ml})$ proteinase K (Merck AG, Darmstadt, Germany), after dilution with $0.4 \mathrm{ml}$ buffer $\mathrm{I}$, for $17 \mathrm{~h}$ at $37^{\circ} \mathrm{C}$, to liberate RNA and DNA from the protein moiety 
of "big"-TSH. The measurement of DNA and RNA was performed using the sensitive fluorescence method with ethidium bromide in the presence of $0.07 \mathrm{~mol} / \mathrm{l}$ magnesium chloride (Paoletti \& Le Pecq 1971), and a Perkin-Elmer fluorescence spectrometer (MPF-2A). The fluorescence emission was monitored at $586 \mathrm{~nm}$ after calibration with calf thymus DNA and with unfractionated yeast t-RNA (Boehringer, Mannheirn, Germany). The limit of detection for DNA was approximately $0.1 \mu \mathrm{g} / \mathrm{ml}$ and for t-RNA $1 \mu \mathrm{g} / \mathrm{ml}$.

\section{Measurement of the biological activity}

The measurement of the biological activity was performed in the laboratory of Dr. von zur Mühlen, Hannover, using the cytochemical bioassay (Bitensky et al. 1974). The biological activity was measured in the three main fractions $\left(\mathrm{K}_{\mathrm{av}}=0,0.3\right.$ and 0.5$)$ of pituitary-TSH chromatographed on Sephadex G-200 and likewise in a guanidinetreated and re-chromatographed "big"-TSH fraction. M. R. C.-TSH-standard A was used for calibration. TSH activities of the same fractions were determined in our laboratory in Munich by radioimmunoassay using M. R. C. 68/38 as standard. Comparison of standard $\mathrm{A}$ and $68 / 38$ in the radioimmunoassay showed standard $\mathrm{A}$ to have $85 \pm 7 \%$ of the activity of $68 / 38$-TSH (Fig. 3).

\section{RES ULTS}

\section{Chromatography of pituitary supernatants}

Chromatograms of the $30000 \times g$ supernatants from human pituitary homogenates on Sephadex G-100 columns always showed turbid fractions eluting in the void volume with TSH-activities of about $1 \%$ of the total TSH-activity (Fig. 1). However, re-chromatography on Sephadex G-200 showed that these fractions from G-100 were not homogeneous, but were separated into TSH-fractions eluting in the void volume of $\mathrm{G}-200\left(\mathrm{~K}_{\mathrm{ar}}=0\right)$, "big"-TSHfractions of $\mathrm{K}_{\mathrm{av}} 0.3$ and regular TSH $\left(\mathrm{K}_{\mathrm{ar}}=0.5\right)$ (Figs. 2 and 3 ). The amount of TSH found in the void volume was dependent on the gravity force during centrifugation, indicating that in these fractions $\mathrm{TSH}$ was still linked to pituitary cell fragments. The further experiments were mainly performed with "big"-TSH $\left(\mathrm{K}_{\mathrm{a}}=0.3\right)$.

\section{Characterizalion of "big"-TSH}

"Big"-TSH, purified only by re-chromatography on Sephadex G-200 or further purified by affinity chromatography, displayed parallelism of its dilution curves to TSH-standards in the radioimmunoassay (Fig. 4). It was eluted on a calibrated Sephadex G-200 column shortly behind bovine catalase (M. W. 240000 ), pointing to a molecular weight of approximately 200000 . The same product chromatographed in the polyacrylamide-gel-electrophoresis in Trisbuffer $\mathrm{pH} 7.5$ migrated with a $R_{F}=0.32$ significantly faster than regular TSH $\left(R_{F}=0.1\right)$, indicating "big"-TSH to be a more negatively charged mole- 


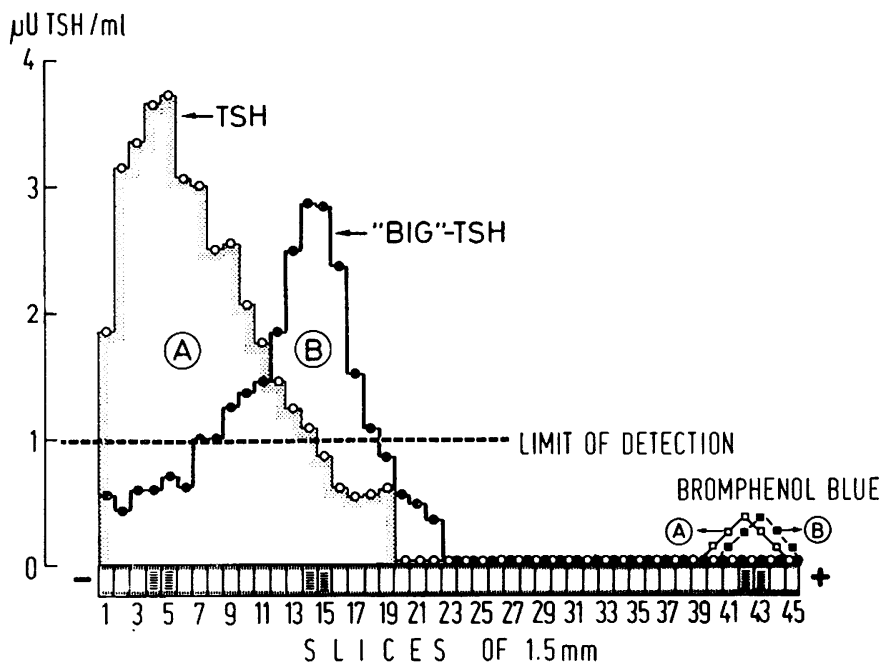

Fig. 5 .

Polyacrylamid-gel-electrophoresis of TSH and "big"-TSH.

A - - Regular TSH (NIAMDD HTSH for labelling).

B - - "big"-TSH.

Gel: $7 \times 0.5 \mathrm{~cm} ; 0.5$ м Tris, $\mathrm{pH} 7.5 ; 5-3 \mathrm{~mA} /$ column.

The TSH-activity was measured by radioimmunoassay in $1.5 \mathrm{~mm}$ slices after elution with buffer B (0.6 ml/slice).

cule (Fig. 5). Affinity chromatography of "big"-TSH on Con A-Sepharose showed that it behaves like a glycoprotein, since it was bound to Con ASepharose like regular TSH. It could also be displaced and eluted by $\alpha$ methyl-D-mannoside.

Measurements of the DNA and RNA content of "big"-TSH, after enrichment by affinity chromatography, using the very sensitive fluorescence method with ethidium bromide displayed DNA and RNA content below the limit of detection: less than $1.5 \%$ DNA and less than $15 \%$ RNA.

All TSH-fractions (Fig. 3), including those treated with guanidine, displayed biological activity. The biological activity of the trypsin-treated fractions have not been measured, because no well defined products were formed.

Purification and yield of "big"-TSH after preparation by affinity chromatography

Affinity chromatography with solid phase anti-TSH after prior separation of a well defined "big"-TSH fraction by Sephadex chromatography, resulted in a $15-40$-fold purification as compared with protein or $\mathrm{HGH}$, respectively, 
Table 1 .

Purification and yield of "big"-TSH from 50 pituitaries by affinity chromatography with anti-TSH-Sepharose and Con A-Sepharose after prior separation from regular TSH and void volume TSH by one chromatography run on Sephadex G 100 and two subsequent runs on Sephadex G 200 (results of one experiment).

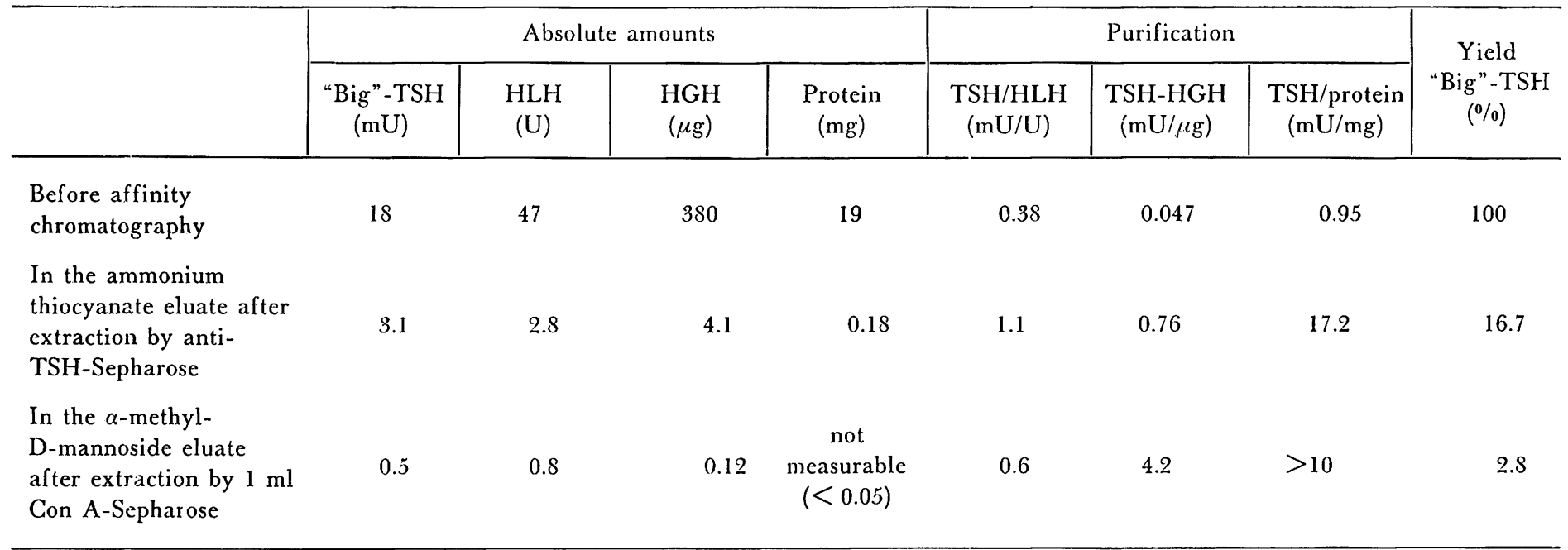




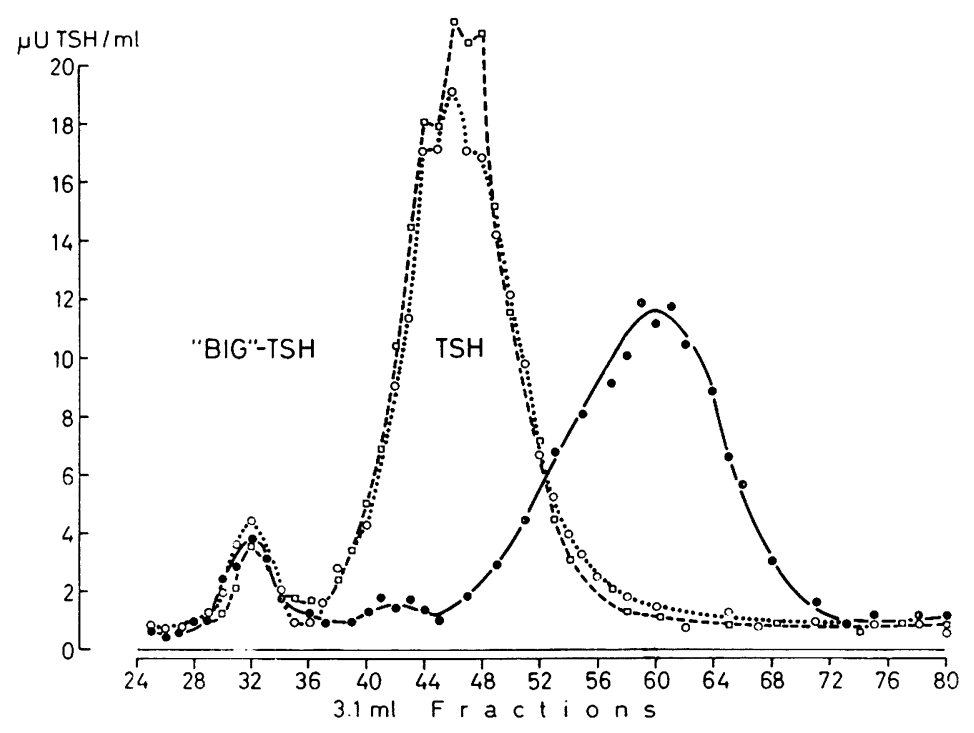

Fig. 6.

Chromatograms of crude "big"-TSH on Sephadex G-100 after various treatments. $\left(127 \times 1.7 \mathrm{~cm}\right.$; buffer $\left.\mathrm{C} ; 4^{\circ} \mathrm{C}\right)$.

1) $\cdots \bigcirc \cdots$ Untreated.

2) $-\square-1 \mathrm{~h} ; 37^{\circ} \mathrm{C} ; 0.25 \%$ Triton X 100; $\mathrm{pH} 7.4$.

3) - $1 \mathrm{~h} ; 37^{\circ} \mathrm{C} ; 0.25 \%$ Triton $\mathrm{X} 100 ; 6$ mol/l guanidine- $\mathrm{HCl} ; \mathrm{pH} 5.1$.

The first peak represents "big"-TSH, the second peak regular TSH, the third peak, only seen on the guadinine-treated material, has not fully been investigated, but possibly contains $\beta$-TSH, which shows almost the same binding characteristics with the antibody as the TSH-standard used in the assay.

and 2-10-fold when compared with HLH. In this step the yield of "big"-TSH dropped from 100 to between 15 and $30 \%$.

Further purification was achieved on Con A-Sepharose, the protein concentration then being below the limit of detection $(<50 \mu \mathrm{g}$ protein $/ \mathrm{ml})$. As compared with $\mathrm{HGH}$ this procedure resulted in a further 5-10-fold purification. However, compared to HLH no further purification was achieved. The yield of "big"-TSH dropped by an additional factor of about 5 .

Table 1 shows the results of one experiment, where the purification of "big"-TSH was approximately 100-fold as compared to somatotrophin.

\section{Stability of "big"-TSH}

In an attempt to convert "big"-TSH to regular TSH and to find some indications concerning the structure of "big"-TSH, the product was treated with $6 \mathrm{~mol} / \mathrm{l}$ guanidine, $1 \%$ mercaptoethanol and trypsin, respectively.

Treatment with $6 \mathrm{~mol} / \mathrm{l}$ guanidine for $1 \mathrm{~h}$ at $37^{\circ} \mathrm{C}$ in the presence of $0.25 \%$ 


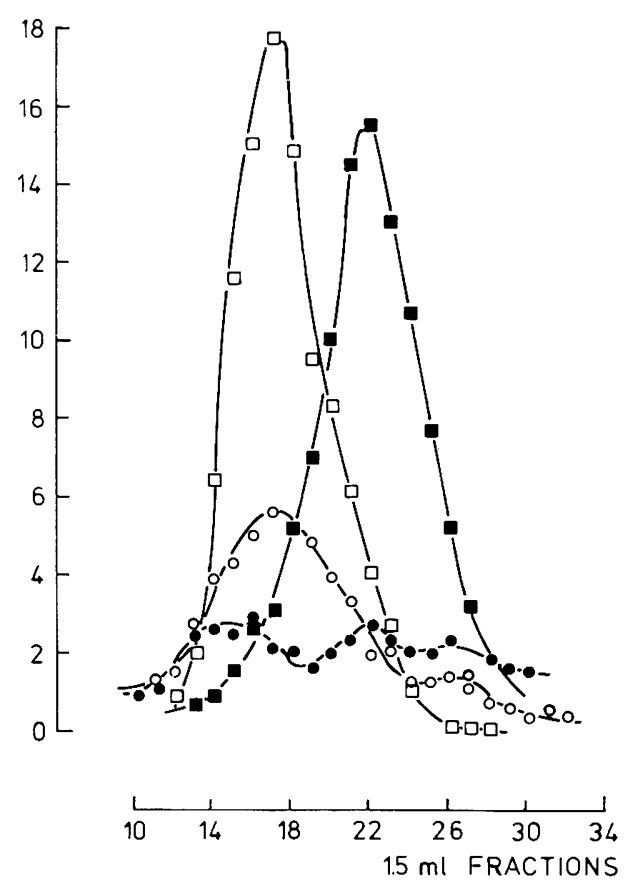

Fig. 7.

Chromatograms of TSH and "big"-TSH on Sephadex G-100 after treatment with mercaptoethanol. $\left(70 \times 1.1 \mathrm{~cm}\right.$; buffer $\left.\mathrm{C} ; 4^{\circ} \mathrm{C}\right)$.

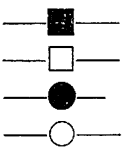
HTSH (M. R. C. 68/38) untreated.

\section{"big"-TSH untreated.}

"big"-TSH in buffer $\mathrm{B} ; 1 \mathrm{~h} ; 37^{\circ} \mathrm{C} ; 1 \%$ mercaptoethanol, pH 7.4.

"big"-TSH $66 \mathrm{~h} ; 4^{\circ} \mathrm{C} ; 1 \%$ mercaptoethanol, $\mathrm{pH} 7.4$.

of the detergent Triton $\mathrm{X} 100$ at $\mathrm{pH} 5.1$ resulted in only a minor degradation of about $10-15 \%$ in contrast to regular $\mathrm{TSH}$, which was almost completely destroyed under the same conditions (Fig. 6). Triton X 100 alone had no significant effect on "big"-TSH. Moreover, the guanidine-treated "big"-TSH did not lose its biological activity, as shown in the cytochemical bioassay (Fig. 3).

Treatment with $1 \%$ mercaptoethanol at $4^{\circ} \mathrm{C}$ and at $37^{\circ} \mathrm{C}$ led to loss of the immunological activity of "big"-TSH and regular TSH at similar rates, so that an intermediate formation of regular TSH from "big"-TSH could not conclusively be shown by this experiment. At $37^{\circ} \mathrm{C}$, both "big"-TSH and reoilar TSH lost $90 \%$ of their immunological activities in the radioimmunoassay. At $4{ }^{\circ} \mathrm{C}$, approximately $50 \%$ was lost within $48 \mathrm{~h}$. Re-chromatography of the mercaptoethanol-treated "big"-TSH showed only a minor peak in the region where regular TSH would be expected (Fig. 7). 
The digestion experiments with trypsin were performed in a mild procedure at $\mathrm{pH} 7.4$ in the absence of calcium. Re-chromatography of the digestion mixture on Sephadex G-200 demonstrated the formation of still immunologically active cleavage products, which were eluted between "big"-TSH and regular TSH, indicating molecular weights between "big"- and "regular" TSH. There was practically no products formed which could be eluted in the volume where TSH should appear (Fig. 2).

So far none of the cleavage experiments have succeeded in the formation of regular TSH from "big"-TSH.

\section{I S C US S I O N}

High-molecular forms of HTSH have not been observed earlier probably because of the minute amounts found in the supernatant of pituitary homogenates, and because of the necessity of using long columns to separate "big" from regular TSH. Additionally, the "big"-TSH-fractions obtained after chromatography on Sephadex G-100 columns are not homogeneous. On Sephadex G-200, turbid fractions can again be obtained, in which TSH is probably still linked to cell-fragments ("void volume-TSH"). The second fraction, which was eluted on G-200 between the void volume TSH and regular TSH, differs mainly in three aspects from regular TSH:

Firstly, it showed a molecular weight of about 7 times that of regular TSH by chromatographic comparison with bovine catalase, secondly, in contrast to regular TSH, "big"-TSH was not cleaved into subunits by $6 \mathrm{~mol} / \mathrm{l}$ guanidine, and finally, it migrated faster on PAGE $\mathrm{pH} 7.5$ when compared with highly purified TSH in spite of its much bigger molecular weight.

This indicates more negatively charged groups, which could for instance be sialic acid groups. As tested by fluorescence with the ethidium bromide method, "big"-TSH contains no DNA or RNA in significant amounts.

However, "big"-TSH also displays a series of features very similar to regular TSH which do not exclude a relationship to regular TSH. Firstly it showed parallelism of its dilutions when compared with standard TSH in the radioimmunoassay, indicating identity of the antigenic sites and good accessibility for the specific antibody, so that the antigenic site does not seem to be folded into the big protein. Moreover, "big"-TSH was bound to Con ASepharose like glycoproteins just as regular TSH and could be displaced readily by $\alpha$-methyl-D-mannoside. These features make it very likely that "big"-TSH contains, in some still unknown manner, regular TSH. The high stability against $6 \mathrm{~mol} / \mathrm{l}$ guanidine is surprising, but is in accordance with the high stability of "big"-LH as described by Prentice \& Ryan (1975). This suggests, that "big"-TSH is not a mere aggregate but a covalently linked product, and indicates in addition, that the subunits in this "big"-TSH may also 
be covalently linked, in contrast to those of regular TSH, which are easily cleaved by $6 \mathrm{~mol} / \mathrm{l}$ guanidine.

We still do not know, if "big"-TSH is a product, in which regular TSH is linked to a second "big"-protein or whether "big"-TSH is a covalently linked polymer of regular TSH. The latter possibility could be clarified, when sufficient amount of purified "big"-TSH has been prepared for the determination of its specific activity. Our attempts to cleave "big"-TSH with mercaptoethanol showed only, that the immunological activity was destroyed in the same way as that of regular TSH under these conditions. From these experiments, we are therefore not able to elucidate on the combining groups in the "big"-TSH. But at the same time we cannot exclude, that disulphide groups play a role in binding.

Our attempts to cleave "big"-TSH by tryptic digestion did not result in the production of regular TSH. This is in contrast to "big"-ACTH, which is transformed to regular ACTH by trypsin as described by Yalow (1974). But at least tryptic digestion products were formed, which still showed immunological activity in the radioimmunoassay and which on re-chromatography on Sephadex Gr-200 displayed molecular weights between "big"-TSH and regular TSH.

Interestingly, regular TSH, as well as "big"-TSH, guanidine-treated "big"-TSH and void volume TSH, showed biological activity in the cytochemical bioassay in good agreement with the radioimmunological findings. This allows the suggestion that in "big"-TSH as in void volume TSH the immunologically/ biologically active sites are accessible to the TSH-receptors of thyroid cells.

The question of the amount of alpha and beta subunits in the "big"-TSH molecule can only be answered when firstly, "big"-TSH has been further purified, mainly using affinity chromatographic techniques with Con ASepharose and solid-phase-anti-TSH, and secondly, when a mild cleavage procedure has been found. Attempts to determine the amount of alpha and beta subunits included in the "big"-TSH, based on measurements in poorly purified Sephadex eluates, are not valid because of the cross-reaction of the accompanying glycoproteohormones and their subunits which complicate the quantitation.

In a few experiments, where serum of hypothyroid patients was chromatographed on Sephadex G-100 or 200 no TSH-activity was found at the position, where "big"-TSH should appear, even with a very sensitive radioimmunoassay (limit of detection $0.1 \mu \mathrm{U} / \mathrm{ml}$ ). Interestingly Golstein-Golaire \& Vanhaelst (1975) and Kourides et al. (1976) reported beta-TSH-subunit-activity in some hypothyroid sera, corresponding to a "big"-beta-TSH with a molecular weight of approximately 160000 . It is still not known whether there is any relationship between the "big"-beta-TSH found occasionally in serum and "big"-TSH regularly present in pituitaries. 
The physiological significance of "big"-TSH is still obscure and open to speculation. Up to date, it cannot be excluded that "big"-TSH is merely a side-product or an oxidation product of no physiological importance. If "big"TSH has any physiological significance, then we rather believe, because of the minute amounts present, that it is an intermediate between an even larger precursor and regular $\mathrm{TSH}$, rather than a storage form, as has been suggested by Golstein-Golaire \& Vanhaclst (1976). The "intermediate" hypothesis can, however, only be proven when we succeed in showing the formation and the disappearance of "big"-TSH in pituitary cells.

\section{A C K N O W L E D M EN T S}

We are indebted to Dr. K. Döhler and Prof. Dr. A. von zur Mühlen, Hannover, for the TSH-measurements in the cytochemical bioassay. We are also grateful to Miss C. Schuster for her technical assistance, Miss B. Glöckner and Miss R. Rothenfusser for HLH- and HGH-measurements, Dr. W. Kerner for the performance of the polyacrylamide-gel-electrophoresis and Dr. M. Kahan and Dr. R. E. Streek for their help in fluorescence measurements of RNA and DNA. This work was supported by the Deutsche Forschungsgemeinschaft SFB 51, Munich.

\section{R E F E R E N C E S}

Bitensky L., Alaghband-Zadeh J. \& Chayen J.: Clin. Endocr. 3 (1974) 363.

Erhardt F. W.: Acta endocr. (Kbh.) Suppl. 193 (1975) 3.

Erhardt F. W., Marschner I., Pickardt C. R. \&. Scriba P. C.: Z. klin. Chem. 11 (1973) 381.

Erhardt F. W. \& Scriba P. C.: V. Internat. Congr. Endocr., Hamburg (1976). Abstract No. 332.

Golstein-Golaire J. \& Vanhaelst L.: J. clin. Endocr. 41 (1975) 575.

Golstein-Golaire J. \& Vanhaelst L.: VII. Annual Meeting of the European Thyroid Assoc. Helsinki 1976. Acta endocr. (Kbh.) Suppl. 204 (1976) Abstract No. 4.

Graesslin D., Leidenberger F., Glismann D., Lichtenberg V. \& Czygan P.: V. Internat. Congr. Endocr., Hamburg (1976). Abstract No. 324.

Greenwood F. C., Hunter W. M. \& Glover J.: Biochem. J. 89 (1963) 114.

Kourides J. A., Weintraub B. D. \& Maloof F.: V. Internat. Congr. Endocr., Hamburg (1976) Abstract No. 333.

Marschner I., Erhardt F. W., Henner J. \& Scriba P. C.: Z. klin. Chem. 13 (1975) 481.

Paoletti J. \& Le Pecq J.-B.: J. molec. Biol. 59 (1971) 43.

Prentice G. \& Ryan R.: J. clin. Endocr. 40 (1975) 303.

Smith I.: Chromatographic and Electrophoretic Techniques, Vol. II. William Heineman Ltd., London (1968).

Yalow R. S.: Recent Progr. Hormone Res. 30 (1974) 597.

Received on October 18th, 1976. 